\title{
Azerbaidžano saugumo strategijos dilema: energetikos politika ar teritorinis vientisumas?
}

Azerbaidžanas, stipriausia Pietų Kaukazo valstybe, tuo pat metu yra ir viena pažeidžiamiausių regione. Viena vertus, šalis jau daugiau nei du dešimtmečius susiduria su teritorinio vientisumo problema dèl „išaldyto“ konflikto su Arménija dèl Kalnų Karabacho regiono. Kita vertus, pastaruoju metu Azerbaidžanas tampa svarbia grandimi Europos energetikos politikoje. Jei Azerbaidžanas pradètu karą dèl Kalnų Karabacho, pastarąjị dešimtmetị vykdyta ambicinga energetikos politika siekiant tapti reikšmingu naftos ir dujų tiekimo iš Rytų ị Vakarus centru, būtų pasmerkta nesèkmei. Visgi tuo pat metu nesureguliuotas dalies šalies teritorijos kontrolès klausimas yra didžiausia kliūtis darniam šalies vystymuisi ir tarptautiniam bendradarbiavimui. Taigi šiuo metu Azerbaidžanas susiduria su dilema - imtis "griežtojo" saugumo priemonių ir atkurti teritorinį vientisumą, apie ką nuolat užsimena aukščiausi šalies politikai, ar visas pastangas skirti į Europą orientuotos energetikos politikos plètrai, teigiamai veikiančiai tarptautinị šalies prestižą. Dar daugiau, kyla klausimas, ar egzistuoja „vidurio kelias“, leidžiantis Azerbaidžanui pasiekti abu aukščiau įvardytus tikslus. Straipsnyje, remiantis struktūrinès ir santykinès galios koncepcijomis, nagrinëjami Azerbaidžano saugumo balanso veiksniai ir pateikiami siūlymai dèl šalies saugumo padèties stabilizavimo.

\section{lvadas}

Azerbaidžaną galima vadinti reikšmingiausia Pietų Kaukazo valstybe: dèl svarbios geostrateginès padeties, gebëjimo palaikyti dialogą tiek su Rytais, tiek su Vakarais bei dèl drąsios ir ambicingos energetikos politikos. Šalis sugebejo iš sudètingą transformaciją išgyvenusios ir vidinių konfliktų draskomos pokomunistinès „pilkosios zonos“ valstybès tapti svarbia JAV ir ES partnere. Kalbant apie Pietu Kaukazą kaip tiltą tarp Rytų ir Vakarų, visų pirma galvoje turimas Azerbaidžanas - be jo Pietų Kaukazo kaip ,jungties“ funkcija sunkiai įsivaizduojama. Anot Zbignevo Brzezinskio, Azerbaidžanas - Pietų Kaukazo geopolitinis centras ${ }^{1}$.

Nors ir būdamas susikertančių geopolitinių interesų epicentre, Azerbaidža-

\footnotetext{
* Laura Kirvelytè- Generolo Jono Žemaičio Lietuvos karo akademijos Štabo karininkų kursų destytoja. Adresas: Šilo g. 5A, 10322 Vilnius, tel. 8-5-210 3569, el. paštas laura.kirvelyte@gmail.com.

1 Бжезинский 3., Великая шахматная доска. Москва: МежАународные отношения, 1999, р. 172-173.
} 
nas siekia kiek įmanoma išbalansuoti tarp skirtingų geopolitinių jègų ir išlaikyti neutralumą. Visgi nuo teorinio neutraliteto modelio šalis gana smarkiai nutolusi jau vien dèl to, kad neatitinka pagrindinio neutraliai valstybei keliamo kriterijaus reikalavimo, kad šalies teritorijoje nebūtų dislokuota jokios kitos valstybès karinių pajègur. Šiandien beveik penktadalis Azerbaidžano teritorijos yra kontroliuojama Arménijos karinių pajëgų.

Paskutiniojo XX a. dešimtmečio pradžioje nepriklausomybę atgavęs Azerbaidžanas tapo tipiška sudètinga pokomunistine valstybe, draskoma posovietinei erdvei būdingo ,išaldyto “ teritorinio konflikto. Faktiškai pralaimëjęs karą dèl Kalnų Karabacho, Azerbaidžanas susidūrè su nuolatine grèsme teritoriniam vientisumui, lydima ekonominių ir socialinių problemų lavinos. Svarbu pabrěžti, kad Baku prarado ne tik fizinę dalies savo teritorijos kontrolę, bet ir pralaimëjo Jerevanui informacini karą dèl savo konflikto versijos įtvirtinimo tarptautinëje bendruomenëje.

Visgi per pirmąji XXI a. dešimtmetį Azerbaidžanas sugebejo reabilituotis tarptautinëje arenoje - patogią geostrateginę padètį ir solidų potencialą energetikos srityje suderinęs su JAV ir ES politika bei intencijomis regione, Azerbaidžanas tapo svarbia šalimi JAV antiteroristineje kampanijoje bei esmine stambaus masto naftos ir dujų transportavimo maršrutų grandimi.

Viena vertus, nesureguliuotas Kalnų Karabacho konfliktas niekur nedingo. Priešingai, kaip pastebi ekspertai, laikas Kalnų Karabacho konflikto sureguliavimo procese bèga ne Baku naudai - kuo ilgiau „išaldyto“ konflikto teritorijoje nèra atkuriama de facto Azerbaidžano kontrole, tuo didesni iššūkiai laukia ateityje, bandant reintegruoti ši regioną i gerokai pakitusią politinę, ekonominę ir socialinę Azerbaidžano aplinką. Dar daugiau, ilgalaikei energijos išteklių transportavimu pagrịstai plètros strategijai realizuoti Azerbaidžanui būtina taika ir stabilumas, o nesureguliuotas teritorinis konfliktas, nuolat verčiantis balansuoti Baku ant karo grèsmés slenksčio, nedidina tarptautinès bendruomenès ir investuotojų pasitikëjimo Azerbaidžanu. 2008-ųjų rugpjūčio karas tarp Rusijos ir Gruzijos leido Azerbaidžanui pajusti nestabilumo kainą - konflikto metu saugumo sumetimais buvo laikinai sustabdyti didieji naftos ir dujų transportavimo vamzdynai (jie eina per Gruziją - L. K.), o vienintelis veikęs naftotiekis buvo Baku-Novorosijskas, kuri prieš kelerius metus svarstyta uždaryti kaip ekonomiškai netikslingą.

Kita vertus, būtent vienašališkas ir skubotas bandymas išspręsti teritorinio vientisumo problemą gali baigtis ne tik dar vienu Azerbaidžano pralaimëjimu Kalnų Karabacho fronte, bet ir daugiau nei dešimtmeti puoselètos energetikos politikos, pagrindinio Azerbaidžano „lango i pasaulį“, krachu. Baku suvokia, kad karo dèl Kalnų Karabacho atveju kariauti reikètų ne vien su Armenija, bet realiai ir su Rusija. Be to, bandymas spręsti teritorinio vientisumo problemą ginklu ne 
tik neduotų greito sprendimo, bet greičiausiai dar labiau komplikuotų situaciją. Galiausiai Baku tarptautinès bendruomenès būtų traktuojamas kaip agresorius, pamynęs taikaus konfliktų sureguliavimo ir jegos nenaudojimo principus. Pasitikëjimo Azerbaidžanu sumažejimas neišvengiamai apribotų šalies energetikos politikos galimybes - pagrindinị Azerbaidžano plètros ,variklį“. Visgi tuo pat metu Azerbaidžanas mato, kad derybos su Arménija viso labo yra „derybų imitavimas“, nevedantis prie problemos sprendimo - konfliktuojančios šalys iki šiol nèra radusios kompromiso net dèl pagrindinių Kalnų Karabacho konflikto sureguliavimo principų.

Energetikos politikos svarbos iškilimas „,ǐgelbëjo “ Azerbaidžaną nuo „išaldytų“ konfliktų kamuojamoms valstybèms būdingo „vienos problemos“ šalies statuso. Akademinëje literatūroje tiek Kalnų Karabacho konfliktui, tiek Azerbaidžano energetikos politikos klausimui skiriamas nemenkas dėmesys. Kalnų Karabacho problemos analizei daug demesio yra skyrę Tarptautinè krizių valdymo grupe (International Crisis Group), Varšuvoje įsikūręs Rytu Europos studijų centras ir Jungtinès Karalystès gynybos akademija (Defence Academy of the United Kingdom); pastaroji yra įnešusi nemažą indèli i Kaspijos energetikos klausimų analizę. Visgi dauguma atvejų Kalnų Karabacho , „išaldyto “ konflikto ir sparčiai besiplètojančios Azerbaidžano energetikos politikos klausimai nagrinejjami izoliuotai vienas nuo kito, lyg nedarytų vienas kitam jokios įtakos.

Šiame straipsnyje pristatomame tyrime siekiama analizuoti Azerbaidžano vystymąsi skatinančią energetikos politiką ir ji stabdantį „išaldyto“ Kalnų Karabacho konfliktą kaip i du konfliktuojančius, bet glaudžiai susijusius tos pačios saugumo strategijos elementus, kurių koegzistavimas lemia trapų Azerbaidžano saugumo balansą. Pristatomo tyrimo tikslas - nustatyti Azerbaidžano saugumo balanso veiksnius ir įvertinti ju poveikị šalies saugumo strategijai. Tai atliekama pasitelkiant santykinès ir struktūrinès galios koncepcijas, leidžiančias ịvertinti Azerbaidžano politiką didejjančios tarpusavio priklausomybès ir daugiašališkumo kontekste, globalios ir regioninès Azerbaidžano saugumo situacijos tyrimą ir šalies atsako į kylančius iššǔkius - saugumo strategijos - analizę.

\section{Galia ir saugumas: struktūrinès ir santykinès galios aspektai}

Anot realistinès tarptautinių santykių prieigos atstovu, jei pagrindinis valstybès tikslas - išlikimas (programa minimum) ir gebejjimas daryti poveikị kitiems tarptautinių santykių veikejjams (programa maximum), tai galios didinimas yra būtina sèkmingo valstybès funkcionavimo tarptautinëje aplinkoje prielaida. 
Analizuojant valstybès galios įtaką saugumui didejjančios tarpusavio priklausomybès tarptautinejje arenoje kontekste labai praverčia tarptautinių santykių teorijos neorealistinès krypties atstovų siūlomas galios sąvokos išskaidymas į dvi koncepcijas - santykinę ir struktūrinę galią.

Santykine galia, dar vadinama galia-potencialu, yra agreguotas valstybès galimybių tarptautineje arenoje rodiklis lyginamojoje perspektyvoje su kitais tarptautinių santykių veikëjais. Pasak Susanos Strange, santykinè galia - tai valstybès „A“ gebëjimas priversti valstybę „B“ daryti tai, ko pastaroji paprastai nedarytu“" Santykinè valstybès galia apima fizinius (teritorija, gyventojų skaičius, naudingosios iškasenos ir t. t.), karinius (kariuomenés dydis, karinis biudžetas, infrastruktūra ir t.t.) ir ekonominius (BVP, rinkos dydis ir t. t.) parametrus, kuriu visuma rodo valstybès „svorị“ kitų valstybių atžvilgiu. Visgi santykine galia, nors ir yra gana lengvai operacionalizuojama ir išmatuojama, yra statiškas rodiklis, parodantis tik valstybès galimybes (potencialą), bet nieko nesakantis apie valstybès gebëjimą panaudoti šį potencialą igyvendinant savo nacionalinius interesus.

„Dinamiškuoju“ galios sąvokos parametru galima laikyti struktūrinę galią, dar vadinamą galia-įtaka. Struktūrinè galia apibrěziama kaip valstybès sugebëjimas nustatyti ar daryti reikšmingą įtaką tarpvalstybinių santykių taisyklèms, problemų darbotvarkei ir sprendimų priëmimo procedūroms. ${ }^{3}$ Struktūrine galia apima tokius parametrus kaip valstybès statusas, prestižas tarptautineje arenoje, valstybes svarba didiesiems geopolitiniams veikëjams, specifinio sektoriaus (struktūros) kontrolè ir pan., ir, kitaip nei santykiné galia, yra vertinama kokybiniais parametrais. Kitaip tariant, struktūrine galia rodo valstybès gebëjimą veikti tarptautinëje arenoje savo nacionalinių interesų labui. Struktūrinè galia gali būti skiriama ị dvi dimensijas: bendrajją struktūrinę galią (valstybès padètį tarptautinëje bendruomenëje) ir specifinę struktūrinę galią (valstybès pozicijas tam tikro konkretaus klausimo ar problemos atžvilgiu $)^{4}$.

Nors struktūrinè galia - sunkiai išmatuojamas parametras, jos aspektas labai svarbus šiuolaikinëje tarptautinëje sistemoje, nes parodo valstybès gebëjimą veikti tarpusavio priklausomybès sąlygomis, valstybès „socialumą“"

Pasak neorealistų, struktūrinè galia gimsta iš daugkartinio santykinès galios panaudojimo ir gali prisidèti prie pastarosios didinimo. Visgi verta pažymèti, kad šiandieninejje tarptautinëje sistemoje, pasižyminčioje augančia tarpusavio priklausomybe ir paremtoje daugiašaliais santykiais, struktūrinès galios svarba išauga - struktūrinè galia ne tik tampa santykinès galios panaudojimo išvestine,

\footnotetext{
${ }^{2}$ Strange S., Valstybes ir rinkos, Vilnius: Eugrimas, 1998, p. 44.

${ }^{3}$ Statkus N. et al, Geopolitiniai kodai: tyrimo metodologija. Vilnius: Vilniaus universiteto leidykla, 2003, p. 85.

${ }^{4}$ Aquirre F. J. G., Power, Asymmetry and Negotiation: a Theoretical analysis, Kent Papers in Politics and International Relations, 1995 , p. 20-22.
} 
bet ir kuria savarankišką „pridètinę vertę“ valstybès galiai. Pavyzdžiui, tarptautinis prestižas gali būti sukurtas nesiremiant „materialiais“ santykinès galios parametrais, o kilti iš valstybès principingų užsienio politikos nuostatų, ekspertinio išmanymo kurioje nors srityje, polinkio remti tam tikrais principais ir vertybèmis pagrịstus tarptautinius sprendimus, tačiau prestižo igijimas gali atnešti ir konkrečios, „materialios" naudos valstybei, palengvindamas užsienio investiciju pritraukimą ar padedamas valstybei įsitraukti į plataus masto tarptautinius projektus.

Be to, svarbu pažymèti, kad mažajai valstybei struktūrinès galios komponentas yra ypač reikšmingas. Dèl dydžio(mažumo) veiksnio tokios valstybès santykinès galios augimas yra ribotas - net ir gerokai padidinusi santykinę galią, mažoji valstybè šiuo aspektu tarptautineje arenoje pranašumą vargu ar igytų. $O$ struktūrinès galios sklaidos ribos kur kas platesnès ir lankstesnès. Kitaip tariant, disponuodama mažesniais ištekliais, tačiau nukreipdama savo veiksmus tikslingai ir teisinga kryptimi, mažoji valstybe gali pasiekti aukštą struktūrinès galios sklaidą, kas kartu didina bendrą valstybès galią.

Žvelgiant ị Azerbaidžano saugumo strategijos dilemą per santykinès ir struktūrinès galios prizmę teoriškai šaliai galimos dvi veiksmų kryptys.

Pirmoji - didinti karinę galią, svarbų santykinès galios komponentą. Išaugus karinei galiai padidètų tikimybè išspręsti Kalnų Karabacho konfliktą artimiausiu metu ir, susigrą̌inus okupuotų regionų kontrolę, nebekiltų grésmè teritoriniam integralumui. Išsprendusi pagrindinę "griežtojo “ saugumo problemą, šalis tarptautinès bendruomenés akyse taptų stabilesnè ir patrauklesné politiniam ir ekonominiam bendradarbiavimui, taigi išaugtų Azerbaidžano struktūrinè galia. Išaugus struktūrinei galiai atitinkamai didètų ir santykinè galia.

Vis delto tokia schema veiktų tik tuo atveju, jei Kalnų Karabacho konfliktas būtų išspręstas taikiai (t.y. dèl augančios karinès galios suveiktų atgrasymo strategija). Jei Kalnų Karabacho problemą būtų bandoma spręsti kariniu būdu, tai Azerbaidžano struktūrinè galia sumažètų nepriklausomai nuo konflikto sprendimo baigties, taigi šalies galios augimas būtų „išaldytas“. Dar daugiau, auganti karine Azerbaidžano galia gali išprovokuoti vadinamąją saugumo dilemą, kai šalis stiprina karinę galią, siekdama užtikrinti savo saugumą, tačiau jos saugumas ne padideja, o atvirkščiai - sumažeja dèl to, kad kitos valstybès (Azerbaidžano atveju - Armènija, Iranas, galbūt ir Rusija) ją ima traktuoti kaip grésmę. O tai sukurtų papildomą įtampą regione, galètu išprovokuoti ginklavimosi varžybas - tai mažintų visų su saugumo dilemos reiškiniu susijusių valstybių saugumą ${ }^{5}$.

\footnotetext{
${ }^{5}$ Tickner J. A., „Saugumo re-vizijos“ žr.: Booth K., Smith S., sudar., Tarptautinių santykiu teorija šiandien, Vilnius: Algarvè, 2000, p. 172.
} 
Antroji galima Azerbaidžano veiksmų kryptis - susitelkti į struktūrinès galios didinimą, svarbiu kurios elementu Baku atveju yra ị Vakarus orientuota energetikos politika. Energetikos politika šiuo atveju priskiriama struktūrinès galios kategorijai: patys mineraliniai ištekliai yra santykinès galios rodiklis, tačiau energetikos politika rodo valstybès elgseną renkantis tarp keleto alternatyvų, kai vienoks ar kitoks pasirinkimas turi poveiki valstybès tarptautinei padéčiai. Solidaus statuso ir palankaus įvaizdžio tarptautinëje bendruomenëje igijimas (bendroji struktūrinè galia) galètų būti transformuojamas į Azerbaidžano pozicijos dèl Kalnų Karabacho problemos palaikymą (specifinè struktūrinè galia). Azerbaidžanas iggautų papildomų svertų ,„̌velniosios“ galios pagalba greičiau išspręsti Kalnų Karabacho konfliktą. Šiuo atveju struktūrinès galios augimo rezultatas būtų sparčiausias įmanomas santykinès galios didëjimas, savo ruožtu generuojantis tolesnị struktūrinès galios augimą. Visgi problemiška yra tai, kad struktūrinès galios augimas bendrą Azerbaidžano galią didina vidutiniu-ilguoju laikotarpiu, t. y. norimas rezultatas negali būti pasiekiamas greitai.

Kaip matome, Azerbaidžano (ar bet kokios mažosios valstybès) atveju santykinès galios augimas nebūtinai veda ị reikšmingą struktūrinès galios išaugimą dèl jau minèto mažumo veiksnio. O struktūrinès galios didinimas beveik visada turi teigiamų pasekmių santykinès galios augimui, tačiau teigiamas struktūrinès galios augimo poveikis realiai pajuntamas vidutiniu-ilguoju laikotarpiu.

\section{Tarptautinè Azerbaidžano saugumo aplinka}

Išorinè Azerbaidžano saugumo situacija - labai heterogeniška. Viena vertus, šalies išorès santykiai gali pasirodyti ,„strigę istorinèse nuoskaudose ir daugeli dešimtmečių tebesitęsiančiuose nesutarimuose. Kita vertus, kai kurie tarptautinio bendradarbiavimo politikos darbotvarkès klausimai, tokie kaip energetika ar kova prieš terorizmą, plètojami labai sparčiai. Siekiant geriau suvokti Azerbaidžano saugumo strategijos pasirinkimus, svarbu susipažinti su globaliu ir regioniniu Azerbaidžano saugumo politikos kontekstu.

\subsection{Azerbaidžano vieta JAV ir ES strategijose}

Azerbaidžano svarbą Vakarams - JAV ir ES - galima vadinti XXI a. fenomenu, nes iki tol Azerbaidžanas neužèmè reikšmingos vietos šių didžiųjų tarptautinès politikos veikëjų strategijose.

Baku svarbą Vakarams lemia trys veiksniai - kova prieš terorizmą, alternatyvių dujų ir naftos tiekimo kelių paieška ir globali demokratijos sklaida. 
Po 2001 m. rugsëjo 11-osios teroristinių išpuolių prieš JAV Baku aktyviai įsitraukè ị kovą prieš terorizmą. JAV verčiant Talibano režimą Afganistane, Azerbaidžanas JAV karinèms pajègoms leido naudotis savo oro erdve ir oro uostais ${ }^{6}$. Greta palankios geostrateginès padèties, Baku svarbą Jungtinèms Valstijoms sustiprina ir veiksnys, kad Azerbaidžanas - sekuliari musulmoniška valstybè ${ }^{7}$, nelinkusi ị religinị ekstremizmą. Baku svarba Vašingtonui kovos prieš „blogio ašies"valstybes požiūriu išlieka ir šiandien, Iranui atsisakant nutraukti branduolinius bandymus. Turint omenyje įtemptus Azerbaidžano ir Irano santykius, Teheranas vargu ar sulauktų Baku palaikymo konflikto su JAV atveju. Visgi tiesioginès Azerbaidžano pagalbos karo su Iranu atveju negaletų tiketis ir Vašingtonas - Azerbaidžanas ir Iranas yra sudarę susitarimą, pagal kurị abi šalys ịsipareigoja neleisti naudotis savo teritorija kariniams veiksmams, nukreiptiems prieš kitą sutarties šalį․

Dèl šalies svarbos JAV kovos prieš terorizmą darbotvarkeje nuo $2002 \mathrm{~m}$. Azerbaidžanas gauna kasmetinę JAV finansinę pagalbą, skirtą karinèms pajegoms modernizuoti ${ }^{9}$. Siekiant išlaikyti regioninị paritetą, analogiška Vašingtono pagalba skiriama Armėnijai ir net Kalnų Karabachui, kuris tiesioginę JAV paramą gauna dar nuo 1998 metų $^{10}$. Tiesioginę Vašingtono pagalbą kariniam sektoriui stiprinti gauna ir Gruzija, tačiau Vašingtono karinè parama Tbilisiui yra glaudaus dvieju šalių politinio bendradarbiavimo rezultatas ir nepatenka į JAV siekio išlaikyti balansą Pietų Kaukaze kontekstą.

Pažymètina, kad JAV politika Azerbaidžano atžvilgiu yra paremta nuolatiniu balansavimu. Viena vertus, Azerbaidžanas yra svarbiausias Vašingtono partneris Pietų Kaukazo regione. Kita vertus, JAV gyvena labai stipri armènų diaspora, kurios lobistai sèkmingai skatina proarmėniškas nuotaikas JAV politikoje, kurios dažnai būna ir antiazerbaidžanietiškos.

Šiuo metu vienas aktualiausių Vakarams yra geoenergetinis bendradarbiavimo su Azerbaidžanu aspektas. Azerbaidžano kaip angliavandenilių (dujų ir naftos) tiekejjo Vakarams funkcija jau yra gana gerai realizuota - $2005 \mathrm{~m}$. pradëjo funkcionuoti naftotiekis Baku-Tbilisis-Džeichanas (Baku-Tbilisi-Ceyhan, BTC), pumpuojantis Azerbaidžano naftą iš Baku ị Turkijos uostą Džeichaną. BTC naftotiekio pralaidumas - $50 \mathrm{mln}$. tonų naftos per metus $(1 \mathrm{mln}$. barelių naftos per

\footnotetext{
${ }^{6}$ Mehtijev E., „Perspectives of the Security Development in the South Caucasus”, Peace and Cooperation Resolution Center, Baku, http://www.bmlv.gv.at/pdf_pool/publikationen/10_ssg_10_meh.pdf, 14102011. ${ }^{7}$ Kotanijan H., „Armenian Security and U.S. Foreign Policy in the South Caucasus”. The Quarterly Journal, Vol III, No.2, June 2004, p. 26-27.

${ }^{8}$ Blandy C. W., „Azerbaijan: Permanently Between Scylla and Charybdis?“, Defence Academy of the United Kingdom, August 2006, p. 4.

${ }^{9}$ German T., „Untagling the Karabakh Knot“, Defence Academy of the United Kingdom, June 2005, p. 7.

${ }^{10}$ Socor V., „US-Azerbaijan Partnership: What It Has Deliverd and Wheree It Falters“, US-Azerbaijan Relations: Stage of the „Strategic Partnership“, The Jamestown Foundation, November 92010 , p. 12.
} 
dieną). Po metų, 2006-aisiais, pradejo veikti dujotiekis Baku-Tbilisis-Erzurumas (BTE). Šio dujotiekio metinis pralaidumas - $20 \mathrm{mlrd}$. kubinių metrų dujų. Naftotiekio BTC ir dujotiekio BTE projektų realizavimas iki šiol vadinamas didžiausiu geopolitiniu JAV laimejjimu Pietų Kaukaze.

Kol kas nerealizuota, bet dideli potencialą turinti Azerbaidžano funkcija Vakarų energetikos strategijoje - tranzito jungtis tarp gausius naftos ir dujų išsteklius turinčių Vidurio Azijos valstybių (Kazachstano, Turkmenistano) ir vartotojų ES. Rytinių Kaspijos baseino valstybių angliavandenilių (naftos ir dujų) gabenimas per Azerbaidžaną padètų mažinti ES energetinę priklausomybę nuo Rusijos ir nestabilių Artimųjų Rytų ${ }^{11}$.

Dar viena svarbi JAV ir ES įsitraukimo į Azerbaidžano reikalus priežastis demokratijos ir universalių normų bei vertybių plètra. JAV ir ES siekis demokratizuoti Azerbaidžaną atlieka dvi funkcijas - negatyvią (atribojančią JAV ir ES nuo iš Artimųjų Rytų sklindančių grèsmių) ir pozityvią (Azerbaidžano kaip jungties tarp Europos ir Azijos funkcija). Azerbaidžano „pralaidumą“ tarptautinio organizuoto nusikalstamumo grupių veikimui siekiama sumažinti remiant politines, teisines ir administracines reformas, pilietinès bendruomenès formavimąsi, skatinant visuomenès atvirumą ir pan.

Tiesa, dèl „atlaidaus“ požiūrio ì Azerbaidžano vidaus politikos procesus JAV ir ES neretai yra kritikuojamos ir kaltinamos „dvigubų standartų“ taikymu. Pasak kritikų, Azerbaidžanas, kaip ir Baltarusija, yra labiausiai nuo ES standartų ir vertybių nutolusi šalis-partneré $\dot{1}^{12}$.

Vidaus politikos procesai Azerbaidžane vidutiniu laikotarpiu gali tapti rimta kliūtimi visapusiškam santykių su Vakarais gilinimui. 2009 m. pradžioje Azerbaidžane patvirtinta Konstitucijos reforma, kuria panaikintas dviejų kadencijų iš eilès limitas eiti prezidento pareigas $^{13}$. 2008 m. Ilhamas Alijevas buvo išrinktas antrajai prezidento kadencijai, o šioji Vakarų bendruomenès neigiamai įvertinta reforma atveria kelią jam likti valdžioje neribotą laiką. Šalyje taip pat neigyvendinamas civilinès ir karinès valdžios atskyrimo principas - šalies Gynybos ministerijai vadovauja pulkininkas generolas Safyras Alijevas. Be to, Azerbaidžano valdžia sistemingai riboja žodžio, spaudos laisvę, opozicijos judejimą.

Galima teigti, kad Azerbaidžano bendradarbiavimas su JAV ir ES yra institucionalizuotas, perejęs iš politinio-deklaratyvaus ị praktinị lygmenį.

\footnotetext{
${ }^{11}$ Herd G. P., Moutsakis F., Black Sea Geopolitics: Dilemmas, Obstacles and Prospects. Conflict Study Research Centre, UK Ministry of Defence, G84, July 2000, 16.

${ }^{12}$ Pelczynska-Nalecz K., Integration orIimitation? EU Policy Towards its Eastern Neighbours, Centre for Eastern Studies, Warsaw, April 2011, Issue 36, p. 18.

${ }^{13}$ The Constitution of the Republic of Azerbaijan, http://www.azerbaijan.az/portal/General/Constitution/ constitution_01_e.html
} 
Su NATO pirmąji dvejų metų trukmès Individualios partnerystès veiksmų planą (IPVP) Azerbaidžanas pasiraše 2005 m., antrasis IPVP su NATO buvo pasirašytas $2008 \mathrm{~m}$., trečiasis - $2011 \mathrm{~m}$. pabaigoje ${ }^{14}$. Azerbaidžanas taip pat prisideda prie Tarptautinių saugumo paramos pajegų (angl. International Security Assistance Forces - ISAF) palaikymo - šiuo metu ISAF pajegose tarnauja 94 Azerbaidžano kariai. Be to, Azerbaidžanas yra suteikęs teisę NATO naudotis savo oro erdve, sausumos ir jūrų keliais, aprūpinant ISAF pajègas Afganistane, taip pat Azerbaidžano teritorijoje veikia centras, kuriame rengiami įvairių sričių afganų specialistai ${ }^{15}$. Praeityje Azerbaidžanas aktyviai prisidëjo prie NATO pajegų veiksmų Irake ir Kosove.

Azerbaidžanas, kartu su kitomis dviem Pietų Kaukazo valstybėmis - Gruzija ir Armènija - i Europos kaimynystès politiką buvo įtrauktas 2004 m., o pirmasis veiksmu planas Europos kaimynystés politikos kontekste buvo pasirašytas 2006 metais. Beje, dokumento pasirašymas užtruko beveik metus, nes Azerbaidžano verslo subjektai buvo užmezgę prekybinius ir komunikacinius ryšius su nepripažintu Šiaurès Kipru, taigi, Graikija iškèlè sąlygą dè šiu ryšiu nutraukimo ${ }^{16}$. Tuo metu girdëjosi svarstymų, kad ES galètų pasirašyti veiksmu planus su Gruzija ir Armenija, kurios dar $2005 \mathrm{~m}$. buvo pasirengusios tai padaryti, o su Azerbaidžanu veiksmų planą pasirašyti tuomet, kai bus nutraukti visi pastarojo ryšiai su Šiaurès Kipru. Tačiau ES nusprende likti prie regioninio požiūrio ì Pietų Kaukazą ir nesukurti naujų regioną dalijančių linijų. Nuo 2010 m. ES ir Azerbaidžanas veda derybas dèl Asociacijos susitarimo su ES turinio.

2009 m. pavasarị Azerbaidžanas kartu su kitomis penkiomis Rytų Europos ir Pietų Kaukazo valstybėmis (Baltarusija, Ukraina, Moldova, Armėnija ir Gruzija) buvo įtrauktas į ES Rytu partnerystès iniciatyvą.

Visgi bendradarbiavimo su ES požiūriu Azerbaidžano pozicijos yra kiek silpnesnès nei kaimyninių Armėnijos ir Gruzijos. Vienas iš aspektų - Azerbaidžanas yra vienintelè valstybè Pietų Kaukaze, nepriklausanti Pasaulio prekybos organizacijai (PPO), o tai apsunkina prekybos su ES liberalizavimo klausimą - ES negali pradèti su Azerbaidžanu derybų dèl plačios ir visapusès laisvosios prekybos erdvès (angl. Deep and Comprehensive Free Trade Agreement-DFTA) ${ }^{17}$.

Kaip jau buvo minèta, Azerbaidžano bendradarbiavimas su Vakarais - naujas reiškinys. İdomu pastebèti, kad Azerbaidžano atveju bendros istorijos neturëjimas

\footnotetext{
${ }^{14}$ RFE/RL, Azerbaijan Steps Up Cooperation With NATO, 2012 m. sausio $11 \mathrm{~d}$.

${ }^{15}$ Socor V., „US-Azerbaijan Partnership: What It Fas Deliverd and Wheree It Falters“ (išnaša 10), p. 9.

${ }^{16}$ International Crisi Group, Conflict Resolution in the South Caucasus: the EU's Role, European Report No.

173, 20 March 2006, p. 9.

${ }^{17}$ Rafal Sadowski, Progress in Integrating the South Caucasus Countries With Europe, Centre for Eastern Studies, Warsaw, 03072012.
} 
yra pozityvus veiksnys, nes leidžia plètoti abipusiais interesais pagrịstą bendradarbiavimą, netrikdomą istorinių nuoskaudų ar nesutarimų.

Dar vienas būdingas JAV ir ES politikos Azerbaidžano atžvilgiu bruožas regioninis požiūris. Kitaip tariant, šie tarptautiniai veikëjai visoms Pietų Kaukazo valstybėms taiko vienodą bendradarbiavimo formulę. Panaši tendencija pastebima ir iš Azerbaidžano pusès - Baku siekia dalyvauti aukščiau išvardytose priemonèse visų pirma dẻl to, kad „neatsiliktų“ nuo Gruzijos ir Armènijos ir nesuteiktų šioms strateginio pranašumo.

\subsection{Regioninè Azerbaidžano saugumo specifika}

Priešingai nei interesais paremti neutralūs santykiai su Vakarais, Azerbaidžano santykiai su kaimyninèmis valstybėmis yra gana įtempti ir aptemdyti nesutarimų bei istorinių nuoskaudų.

Problemiškiausi yra Baku santykiai su kaimynine Armenija. Dèl nesureguliuoto Kalnų Karabacho konflikto šalys jokių tarpvalstybinių santykių nepalaiko nuo 1992 m., Kalnų Karabacho karo pradžios.

Armenijos veiksnys veikia ir ypač tvirtais ir draugiškais laikomus Azerbaidžano santykius su strategine partnere Turkija. Ankara, palaikydama Baku Kalnų Karabacho konflikte, 1992 m. uždare valstybinę sieną su Armènija, ir ji išlieka uždaryta iki šiol. Visgi nuo 2008 m. stebimi Turkijos ir Armenijos bandymai normalizuoti dvišalius santykius, igavę „futbolo diplomatijos“"18 pavadinimą, pablogino Azerbaidžano santykius su Turkija. Santykių atšalimo pasekmè - tarp Baku ir Ankaros vis dažniau iškylantys nesutarimų dẻl energijos išteklių tranzito per Turkiją sąlygų.

Azerbaidžano santykiai su kaimynine Gruzija gali būti įvardijami kaip labai geri, vienintelis tarp šalių išlikęs nesutarimas - teritoriniai ginčai dẻl valstybinès sienos, kertančios Gruzijos istorini palikimą, delimitavimo, tačiau jie nèra aktyviai keliami. Gruzija Azerbaidžanui svarbi kaip regioninių energetikos ir transporto projektų partnerè.

Bene daugiausia įtampos taškų Azerbaidžanas turi su kaimyniniu Iranu. Visų pirma Iranas rèmé Arméniją Kalnų Karabacho karo metu 1992-1994 m., o ir šiandien su Jerevanu palaiko glaudžius santykius. Antra, nors abi valstybès musulmoniškos, Azerbaidžanas pabrěžia savo sekuliarumą ir vengia bet kokių sąsajų su radikaliu Iranu. Trečia, Iranas ir Azerbaidžanas nesutaria dèl Kaspijos jūros

\footnotetext{
${ }^{18}$ „Futbolo diplomatijos“ pavadinimas prigijo todel, kad pirmasis Armènijos ir Turkijos prezidentų susitikimas 2008 m. įvyko Armenijoje, stebint dviejų šalių komandų futbolo rungtynes.
} 
teisinio statuso, kas stabdo energetikos projektų Kaspijos jūros baseine plètrą, o kartu - ir riboja Azerbaidžano galią.

Vienas iš veiksnių, verčiančių abi šalis laikytis nuosaikiai viena kitos atžvilgiu - Šiaurès Irane gyvenanti gausi azerbaidžaniečių diaspora. Remiantis įvairiais duomenimis, Šiaurès Irane gyvena 20-30 mln. etninių azerbaidžaniečiu (pačiame Azerbaidžane $-9 \mathrm{mln}$.). Viena vertus, Iranas vengia separatistines tendencijas galinčios paskatinti „Didžiojo Azerbaidžano“ atkūrimo retorikos, kuri ypač reiškèsi tuoj po SSRS subyrëjimo ${ }^{19}$. Beje, $2012 \mathrm{~m}$. vasarị keletas Azerbaidžano parlamentarų pateiké siūlymą pervardyti šali i i „Šiaurès Azerbaidžanas“, taip pabrěžiant, kad Pietuose (Šiaures Iranas) gyvena didele dalis azerbaidžaniečių ${ }^{20}$. Kita vertus, Baku taip pat nèra suinteresuotas, kad Teheranas blogintų jo tautiečių gyvenimo sąlygas šalyje. Vienas iš bendradarbiavimo pavyzdžių - energijos išteklių tiekimas per Iraną nuo Azerbaidžano atskirtai Nachičevanès autonominei respublikai.

Rusijos ir Azerbaidžano santykiai taip pat patenka ị bendrą regionini susipriešinimo kontekstą. Prie dvišalių santykiu aštrinimo prisideda ir bendra Rusijos strategija Pietų Kaukazo regiono atžvilgiu, paremta regiono „skaldymu“ ir ị skirtumus tarp šalių orientuota politika.

Visų pirma, Azerbaidžano ir Rusijos bendradarbiavimą stabdo faktas, kad Kalnų Karabacho konflikto 1992-1994 m. metu Rusija kariavo Armenijos puseje, teike Armenijai ir Kalnų Karabachui ginklus, finansinę pagalbą ir maistą. Be to, Jerevanas iki šiol išlieka svarbiausias Maskvos partneris Pietų Kaukaze.

Antra, Rusijos ir Azerbaidžano santykius Maskva mato per „imperinès atminties“ prizmę, o Baku netenkina buvimas išimtiniu Rusijos interesų objektu. Maskvai iki šiol sunku suvokti ir susitaikyti su tuo, kad ji turi labai mažai svertų kontroliuoti Baku politiką. Vienas charakteringiausių pavyzdžiu šioje srityje galetų būti Gabalos radiolokacinès stoties Azerbaidžane atvejis: Rusija dar sovietmečiu pastatytą radarą nuomojasi iš Azerbaidžano, tačiau nuomos sutartis baigiasi $2012 \mathrm{~m}$. Nepaisant Rusijos bandymų pratęsti stoties nuomos terminą, Azerbaidžanas, atrodo, nelinkęs keisti savo pozicijos.

Trečia, Maskvai sunku susitaikyti su tuo, kad Azerbaidžanas noriai dalyvauja igyvendinant Rusiją apeinančius naftos ir dujų tiekimo alternatyvius maršrutus. ${ }^{21}$. Rusijos tikslas - energijos išteklių tiekimo kontrole, todèl vienas iš Maskvos politikos svertų Azerbaidžano atžvilgiu - Kaspijos jūros teisinio statuso klausimas. Šiuo

\footnotetext{
${ }^{19}$ Ergun, „International Challenges and Domestic Preferences in the Post-Soviet Political Transition of Azerbaijan”, in. Amineh M. P, Houweling H. (eds.), Central Eurasia in Global Politics: Conflict, Security and Development, $2^{\text {nd }}$ ed, Boston: Brill, 2005, p. 334.

${ }^{20}$ Paul Goble, Azerbaijan Republic Should Be Renamed Northern Azerbaijan, Milli Majlis Deputies Say, Azerbaijan in the World. An Electronic Publication of Azerbaijan Diplomatic Academy, Vol V No 4, 15 February 2012.

${ }^{21}$ Falkowski M, Russia's Policy in the Southern Caucasus and the Central Asia, Centre for Eastern Studies,

Warsaw, June 2006, p. 75.
} 
aspektu Rusija remia Irano nelanksčią poziciją ir taip „ׁ̌̌aldo“ gausius energijos išteklius turinčiu šalių abipus Kaspijos krantų energetinị bendradarbiavimą, o kartu - ir alternatyvių energijos išsteklių tiekimo Europai maršrutų plètrą.

\subsection{Azerbaidžano saugumo strategija}

Saugumo strategiją šiame tyrime apibrěšime kaip visumą valstybès pasirinkimų užsienio ir saugumo politikos srityse, fiksuojamų politiniuose dokumentuose ir nuolat pasikartojančių politinejje praktikoje. Svarbu pabrèžti, kad saugumo strategija apima ir esamas garantijas (bendradarbiavimo priemones), ir aspiracijas.

Valstybès saugumo strategijos principai nebūtinai turi būti fiksuojami strateginiuose dokumentuose - tuo atveju, kai jų nèra priimta, vadovaujamasi politines praktikos stebėsena. Visgi strateginių užsienio ir saugumo politikos dokumentų funkcija - išlaikyti užsienio ir saugumo politikos tęstinumą bei informuoti tarptautinę bendruomenę apie valstybès intencijas minètoje srityje. Azerbaidžano saugumo strategijos principai užfiksuoti $2007 \mathrm{~m}$. patvirtintoje Nacionalinio saugumo koncepcijoje ${ }^{22}$. Pagrindinès dokumente išskiriamos grèsmès yra tokios:

- grèsmès Azerbaidžano nepriklausomybei, suverenitetui, teritoriniam integralumui ir konstitucinei tvarkai;

- trukdymas valstybei vykdyti teisès viršenybę, užtikrinti viešąją tvarką, pagrindinių žmogaus teisių bei laisvių apsaugą;

- separatizmas, etninis, politinis bei religinis ekstremizmas; terorizmas ir masinio naikinimo ginklu plitimas; regioniniai konfliktai ir organizuotas tarptautinis nusikalstamumas (šiai gresmei priskiriama ir Armenijos okupuotų Azerbaidžano nekontroliuojamų teritorijų egzistavimas ${ }^{23}$ );

- veiksmai, nukreipti prieš Azerbaidžano energetinę infrastruktūrą (šiame punkte akcentuojama pajamų, gaunamų iš prekybos energijos ištekliais ir jų transportavimo ${ }^{24}$, tačiau neatsižvelgiama ị Azerbaidžano, kaip stabilaus ir patikimo partnerio energetikos srityje, vaidmens svarba);

- kariné, politinè ar ekonominé priklausomybé nuo išorés jègų (atkreiptinas demesys, kad pernelyg didele priklausomybe nuo bet kokių išorés jègų yra įvardijama kaip grésmé; tai paaiškina, kodèl Azerbaidžanas pasirinko neutralią saugumo strategija);

\footnotetext{
${ }^{22}$ National Security Concept of the Republic of Azerbaijan, approved by the instruction No. 2198 of the President of the Republic of Azerbaijan on 23 May 2007, http://merln.ndu.edu/whitepapers/Azerbaijan2007. pdf , 17082011.

${ }^{23}$ Ten pat (išnaša 22), p. 5.

${ }^{24}$ Ten pat (išnaša 22), p. 6.
} 
- ekonominé destabilizacija (pabrěžiama per didelès priklausomybès nuo naftos ir dujų sektoriaus grèsmé);

- kvalifikuotų žmogiškųjų išteklių trūkumas;

- regiono militarizacija (kalbama apie neproporcingą ginklų akumuliavimą bei užsienio karinių bazių egzistavimą šalyje), kuri kelia grésmę regiono saugumui. Paradoksalu, tačiau Azerbaidžanas pastaruosius keletą metų yra sparčiausiai besiginkluojanti valstybe regione, nors ir neturinti užsienio karinių bazių;

- ekologinès grèsmès.

Ekspertų vertinimu, Azerbaidžano Nacionalinio saugumo koncepcija - labai abstraktus dokumentas, mažai nutolęs nuo „chrestomatinių“ šios srities pavyzdžių. Dar iki Nacionalinio saugumo koncepcijos prièmimo Baku patyre nemenką spaudimą iš tarptautinès bendruomenès, esą šalis vengia priimti aukščiausio strateginio lygmens saugumo politikos dokumentą, nes nenori atskleisti savo užsienio ir saugumo politikos prioritetų. Turint omenyje abstraktų dokumento turinį, Baku pavyko ,ǐ̌vengti“ aiškaus pasirinkimo net ir prièmus dokumentą. Visgi Nacionalinio saugumo koncepcijoje išvardijamų grèsmių sąraše galima ižvelgti kai kurias Azerbaidžano saugumo politikos ypatybes.

Visų pirma, gressmių sąrašo pradžioje, kaip ir reikia tikètis, įvardyta grèsmè Azerbaidžano nepriklausomybei, suverenitetui, teritoriniam integralumui, taip pat yra pamineta ir separatizmo grésmè. İdomu tai, kad dokumente įvardytos ir tos grèsmès, kurių šaltinis yra pats Azerbaidžanas, tokios kaip regiono militarizacija.

Antroji grèsmių grupe rodo Azerbaidžano aspiracijas būti stabiliu ir patikimu tarptautinès bendruomenès partneriu. Šiai grupei priskirtinos etninio, politinio bei religinio ekstremizmo grèsmé, terorizmas, masinio naikinimo ginklų plitimas, veiksmai, nukreipti prieš Azerbaidžano energetinę infrastruktūrą.

Ir galiausiai, Nacionalinio saugumo koncepcijoje daug dèmesio skiriama Azerbaidžano nepriklausomumo ir savarankiškumo tarptautineje arenoje svarbai. Politinès ar ekonominès priklausomybès nuo išorès jegu grèsmès ịvardijimas leidžia kalbèti apie tai, kad Azerbaidžanas renkasi neutralią saugumo strategiją, nors žodis „neutralitetas" dokumente ir nèra naudojamas.

Azerbaidžano siekis likti skirtingų geopolitinių interesų susidūrimo epicentro nuošalyje yra labiau jaučiamas politineje praktikoje nei matomas dokumentuose. Azerbaidžanas neturi jokių konkrečių išorinių saugumo garantijų (Armenijos atvejis) ir nedemonstruoja siekio ateityje jas igauti (Gruzijos atvejis). Azerbaidžano dalyvavimas Individualios partnerystès veiksmu plane su NATO yra daugiau ne tikslingo Baku siekio rezultatas, o NATO regioninio požiūrio ị Pietų Kaukazą išdava ${ }^{25}$ Be to, Baku neslepia, kad nèra suinteresuotas naryste Aljanse, o bendradar-

\footnotetext{
${ }^{25}$ Grigoryan S., "The future of Southern Caucasus in the light of new geopolitical reconfiguration". Lithuanian foreign policy review, No. 20, 2008, p. 102-111, 104.
} 
biavimą su NATO mato kaip galimybę modernizuoti savo karines pajeggas. ${ }^{26} \mathrm{Be}$ to, bendradarbiavimas su Aljansu padeda formuoti teigiamą šalies ịvaizdį tarptautinëje bendruomenëje, o tai didina Azerbaidžano struktūrinę galią.

$2010 \mathrm{~m}$. vasarą, praëjus trejiems metams po Nacionalinio saugumo strategijos patvirtinimo, Azerbaidžanas prièmè karinę doktriną ${ }^{27}$. Šiame dokumente dominuoja du leitmotyvai - pabrěžiamas Azerbaidžano neutralumas ir išryškinamas Kalnu Karabacho problemos opumas. Galima teigti, kad karinëje doktrinoje įtvirtintas „perspëjimas“, kad Azerbaidžanas neatmeta karinio Kalnų Karabacho problemos sureguliavimo būdo. Tai gali būti signalas tarptautinei bendruomenei - jei pastaroji nepadès Azerbaidžanui veiksmingai išspręsti teritorinio vientisumo problemos, Baku šią grèsmę neutralizuos savo nuožiūra.

Viena iš pagrindiniu priežasčių, kodèl su grèsme teritoriniam integralumui susiduriantis Azerbaidžanas bando išlikti neutralus - energetikos politika. Neutralumas Baku suteikia galimybę vykdyti plačią energetikos politiką visomis imanomomis kryptimis ir taip stiprinti ekonominị šalies potencialą. Siekdamas maksimaliai išnaudoti strateginių išteklių teikiamas galimybes, Azerbaidžanas nuosekliai stengiasi išbalansuoti tarp didžiųju galių.

\section{Kalnų Karabacho konfliktas - kertinè Azerbaidžano saugumo problema}

Konfliktas dèl Kalnų Karabacho tarp Armėnijos ir Azerbaidžano - didžiausias ịtampos šaltinis Pietų Kaukaze. Būtent dèl šio neišspręsto konflikto egzistuoja griežtas ir nelankstus regioninis pasidalijimas ị „draugus" ir "priešus“.

Užsitęsęs Kalnų Karabacho konfliktas Azerbaidžanui yra aukščiausio lygio grèsmé - grésmé šalies teritoriniam vientisumui. Problemą dar labiau komplikuoja tai, kad konfliktuojančioms Arménijai ir Azerbaidžanui kol kas sunkiai sekasi rasti „pozityvios sumos" konflikto sprendimo variantą.

Šiame skyriuje analizuojamas vidinis (procesai, vykstantys tarp konfliktuojančių šaliu) ir išorinis (tarptautinès bendruomenès tiesioginis ar netiesioginis ịsitraukimas ị konflikto sprendimą) Kalnų Karabacho konflikto aspektai.

\subsection{Kalnų Karabacho konflikto eiga ir specifika}

\footnotetext{
${ }^{26}$ Iš pokalbio su Azerbaidžano karinių pajęgų atstovu plk. Vugar Asgarov tarptautinio seminaro "Enlargement experience course: Lithuania's experience of integration into transatlantic community". Political science department, Military Academy of Lithuania, Vilnius, 20070518

${ }^{27}$ RFE/RL, Azerbaijan Adopts Military Doctrine At Long Last, 2010 m. birželio 9 d.
} 
Kalnų Karabacho konfliktas buvo „užprogramuotas“ dar Sovietų Sąjungos kūrimosi pradžioje - $1921 \mathrm{~m}$. nuspręsta ši gausiai armẻnų gyvenamą regioną, turintį komplikuotą istorinę priklausomybę, prijungti prie Azerbaidžano SSR. Etniškai ginčytinų regionų priskyrimas valstybei - tipine „skaldyk ir valdyk“ politikos apraiška, turëjusi veikti kaip saugiklis valstybių atsiskyrimui nuo Sovietų Sąjungos.

1988 m. Kalnų Karabacho autonominio regiono armènų bendruomenès atstovai ketino kreiptis ị Armenijos SSR ir Azerbaidžano SSR, prašydami priskirti Kalnų Karabachą Armènijos SSR. Tuomet pradejo kilti pirmosios etninès įtampos regione. 1989 m. gruodžio 1 d. Arménijos SSR Aukščiausioji Taryba priemé nutarimą dèl Kalnų Karabacho autonominio regiono priskyrimo Armènijos SSR, tačiau Sovietų Sajungos Aukščiausioji Taryba tokiam žingsniui nepritare, nes nebuvo gautas Azerbaidžano sutikimas ${ }^{28}$.

Azerbaidžanui paskelbus nepriklausomybę 1991 m. rugpjūčio 30 d., Armènija jokių teritorinių pretenzijų formaliai nepareiškè, tačiau etninę įtampa Kalnų Karabache toliau augo. Kariniai veiksmai Azerbaidžano teritorijoje prasidèjo $1992 \mathrm{~m}$. pradžioje ir tęsèsi iki $1994 \mathrm{~m}$. gegužès mėnesio, kuomet buvo pasirašytas ugnies nutraukimo susitarimas, tebegaliojantis iki šiol. Nuo tada konfliktą galima laikyti „„šsaldytu“.

Armenijos karinès pajegos, tiesiogiai padedamos Sovietų Sąjungos (vèliau - Rusijos) kariuomenès ir netiesiogiai (materialia pagalba) remiamos Irano, peremè ne tik Kalnų Karabacho, bet ir septynių regioną supančių Azerbaidžano regionų - Lačino, Kelbažaro, Agdamo, Fizulio, Žabrailo, Gubadlio ir Zangilano - kontrolę. Šiuo metu Azerbaidžanas nekontroliuoja beveik penktadalio savo teritorijos ${ }^{29}$

Žuvusiųjų skaičius Kalnų Karabacho karo metu siekè 22-25 tūkst. ${ }^{30}$. Pabègèliais tapo per 17 tūkst., perkeltaisiais asmenimis - per 660 tūkst. Azerbaidžano gyventojų $u^{31}$ ir atitinkamai 18 tūkst. ir 8 tūkst. armenų ${ }^{32}$. Po karo Azerbaidžaniečiu turëjo didžiausią pabégèlių ir perkeltujjų asmenų santykinę dalị (apie 10 proc.) pasaulyje $^{33}$. Azerbaidžano valstybinis komitetas pabėėlių ir perkeltųjų asmenų

\footnotetext{
${ }^{28}$ Avakyan S., Nagorno-Karabakh Legal Aspects, French University of Armenia, 2005, p. 9.

${ }^{29}$ Ministry of Foreign Affairs of the Republic of Azerbaijan, Map „The Results of Armenin Aggression“, http://mfa.gov.az/images/stories/ermenistan_tecavuzu.jpg, 25102011.

${ }^{30}$ International Crisis Group, Armenia and Azerbaijan: Preventing War, Policy Briefing, European Briefing No. 60, 8 February 2011, p. 2.

${ }^{31}$ Internal Displacement Monitoring Centre, Azerbaijan, http://www.internal-displacement. org/8025708F004CE90B/(httpCountries)/2E505E95ABC577FA802570A7004C6378?OpenDocument, 20 072011.

32 Internal Displacement Monitoring Centre, Armenia, http://www.internal-displacement. org/8025708F004CE90B/(httpCountries)/BDE4E7B8F3758AE6802570A7004C38A1?OpenDocument, 20072011 . .

${ }^{33}$ Socor V., „US-Azerbaijan Partnership: What It Has Deliverd and Wheree It Falters“ (išnaša 10), p. 12.
} 
klausimams pateike skaičiavimus, kad nuo Kalnų Karabacho konflikto pradžios Azerbaidžanas patyre $87 \mathrm{mlrd}$. JAV dolerių nuostolių ${ }^{34}$.

Be to, padètis tarp Armènijos ir Azerbaidžano karinių pajëgų fronto linijoje neprimena , ¡šaldytos“ - dẻ apsišaudymu iš abiejų nesutariančių pusių iki šiol kasmet žūva apie 25-30 karių ${ }^{35}$. Beje, Baku atsisako atitraukti savo snaiperius, ko nuolat reikalauja ESBO Minsko grupe.

Kalnų Karabachas šiandien funkcionuoja kaip nepripažinta valstybè. 1991 m. čia surengto referendumo metu gyventojai pasisakè už regiono nepriklausomybę, tačiau šiandien Kalnų Karabacho nèra pripažinusi nè viena pasaulio valstybè. Tiesa, Armenija periodiškai naudoja Kalnų Karabacho pripažinimo „kortą“ kaip šantažo įrankị prieš Azerbaidžaną ir tarptautinę bendruomenę ${ }^{36}$.

Kalnų Karabacho konfliktas yra specifinis bendrame posovietinëje erdvëje

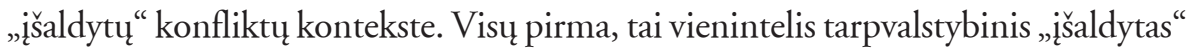
konfliktas. Antra, Rusijos dalyvavimas šiame konflikte yra netiesioginis - pasireiškiantis tik per visokeriopą paramą Armenijai ir per dalyvavimą ESBO Minsko grupès veikloje. Trečia, Kalnų Karabache iki šiol nèra dislokuota jokių taikdariškų pajëgų. Rusija siekia, kad Kalnų Karabache būtų dislokuoti Rusijos taikdariai su ESBO mandatu. Azerbaidžanas tokioms perspektyvoms nepritaria, nes pirmiausia nemato būtinybès regione dislokuoti taikdariškas pajègas, o jei būtų neišvengiama tai daryti, tuomet pasisako už neutralių (be Rusijos) multinacionalinių tarptautinių pajegų dislokavimą. Dar daugiau, Azerbaidžanas - aktyvus antirusiškos GUAM narys ir vienas iš GUAM taikdariškų pajègų sukūrimo iniciatorių. Minètos pajègos visų pirma planuojamos kurti kaip galinčios būti dislokuotos GUAM narių (Gruzija, Ukraina, Azerbaidžanas, Moldova), ,išaldytų" konfliktu zonose.

Galiausiai yra pastebimas Kalnų Karabacho vengimas būti tapatinamam su kitomis nepripažintomis valstybemis posovietinejje erdvëje - Padniestre, Abchazija ir Pietų Osetija. Kalnų Karabachas atsisake jungtis ir prie 2006 m. Suchumyje (Abchazija) įkurtos posovietinès erdvės nepripažintas valstybes vienijančios „Demokratijos ir žmogaus teisių bendrijos “37.

\footnotetext{
${ }^{34}$ RFE/RL, Azerbaijan Evaluates Costs of Nagorno-Karabakh War, 2010 m. birželio 18 d.

${ }^{35}$ International Crisis Group, Conflict Resolution in the South Caucasus: the EU's Role (išnaša 16), p. 3.

${ }^{36}$ Asbarez., Armenia Will Recognize Karabakh if Azerbaijan Resorts to Aggression, Says Sarkisian, $2010 \mathrm{~m}$. gruodžio $2 \mathrm{~d}$.

${ }^{37}$ Kapitonenko M., „Resolving Post-Soviet „Frozen Conflicts“, Per Concordiam, Journal of European Security and Defence Issues, Vol 1, No. 2, June 2010, p. 36.
} 


\subsection{Armènijos ir Azerbaidžano pozicijos „išaldyto“ konflikto atžvilgiu}

Nepaisant mažesnio išorés jëgų (Rusijos) įsikišimo ị Kalnų Karabacho „išaldyto" konflikto reguliavimą, šio konflikto sprendimo eiga yra labai komplikuota.

Pirmoji kliūtis pažangai konflikto sprendimo srityje - radikaliai priešingos konfliktuojančių šalių - Armènijos ir Azerbaidžano - pozicijos. Arménija, ape-

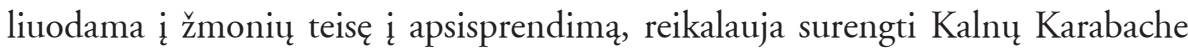
referendumą dèl regiono statuso, po kurio ji sutinkanti atitraukti savo karines pajègas iš Azerbaidžano teritorijos. Azerbaidžanas surengti referendumą sutiktų tik po to, kai iš jo teritorijos būtų patrauktos Arménijos karinés pajègos ir į Kalnų Karabachą būtų grąžinti pabejgèliai ir perkeltieji asmenys iš Azerbaidžano (iki konflikto pradžios 21,5 proc. regiono gyventojų sudare azerbaidžaniečiai). Be to, Azerbaidžanas sutinka tik su Kalnų Karabacho konflikto sprendimu savo teritorinio integralumo principo kontekste. Taigi aukščiausias Kalnų Karabachui galimai suteiktas laisvès lygis būtų plati autonomija.

Antroji kliūtis, apsunkinanti kompromiso paiešką - abiejų valstybių visuomenių jautrumas Kalnų Karabacho klausimu. Tiek Arménijos, tiek Azerbaidžano visuomenés yra gerokai radikalesnés nei politikai ir menkiausią savo šalies atstovų bandymą leistis į kompromisą traktuoja kaip valstybès išdavystę. Dèl šios priežasties politikai, nenoredami prarasti populiarumo visuomenejje ir siekdami išvengti grèsmès būti „išbalsuoti“, metai iš metų laikosi radikalių ir nelanksčių pozicijų. "Galimybių langą“ - laikotarpi, kai ne vienoje iš konfliktuojančių valstybių nevyksta jokie svarbūs politiniai ịvykiai (rinkimai, referendumai), rasti labai sunku, ypač turint omenyje, kad kompromiso paieškos yra ilgas procesas.

Galiausiai Azerbaidžanas nepalaiko jokio dialogo su pačiu Kalnų Karaba$\mathrm{chu}^{38}$ - pastarasis iš derybų proceso Baku iniciatyva buvo pašalintas 1998 m., o šio regiono interesams derybose atstovauja Armenija. Viena vertus, separatistinio regiono dalyvavimas už derybų stalo konfliktuojančios šalies statusu gali išprovokuoti „amžino stabdžio“ problemą. Kita vertus, jei sprendimas dèl Kalnų Karabacho konflikto sprendimo netenkintų paties regiono, tai paliktų separatizmo grèsmę atvirą net ir po to, kai Arménija ir Azerbaidžanas sutartų dẻl Kalnų Karabacho problemos sprendimo.

Taigi abi konfliktuojančios šalys tvirtai laikosi jokių bendrų sąlyčio taškų neturinčių pozicijų jau beveik du dešimtmečius. Priežastis, kodèl jos nejuda kompromiso link - Azerbaidžanas nuolaidų teritorinio vientisumo klausimu daryti negali, o Arménijai status quo situacija yra naudinga, nes, pirma, „išaldytas“

${ }^{38}$ German T., (išnaša 9), p. 2. 
konfliktas vyksta ne jos teritorijoje, antra, nesureguliuotas konfliktas yra vienas iš Armėnijos derybinių svertų tarptautinëje politikoje.

Azerbaidžano politikai ne kartą yra viešai pareiškę, jog jei Arménija ir toliau „imituos derybas“, t.y. jei derybų kelias rezultatų neduos, tuomet Baku neatmeta galimybès pasitraukti iš derybų ir konfliktą spręsti kariniu būdu ${ }^{39}$.

Tokių Baku grasinimų svarumą iliustruoja ir Azerbaidžano karinių išlaidų dinamika. Drastiškas ginklavimosi išlaidų augimas stebimas nuo 2004 m. 2003 m. pabaigoje Azerbaidžano prezidento poste Heidarą Alijevą pakeite jo sūnus Ilhamas Alijevas, turintis gerokai ,griežtesnị " požiūrị i Kalnų Karabacho konflikto sprendimą ${ }^{40}$. 2003 m. Azerbaidžano karinès išlaidos sieke 135 mln. JAV dolerių, o 2011-aisiais jos išaugo daugiau nei 23 kartus ir sudare 3,12 mlrd. JAV doleriu, kas sudaro net 20 proc. šalies BVP ${ }^{41}$. Be to, $2005 \mathrm{~m}$. Azerbaidžane ịkurtos naujos jëgos ministerijos: karinès pramones ${ }^{42}$ ir nepaprastujų situacijų $u^{43}$.

Sparčiai augant Azerbaidžano kariniams pajëgumams, didëja ir Armènijos karinès išlaidos. Visgi Jerevano galimybès akumuliuoti karinę galią yra kur kas labiau ribotos nei Baku, todèl Armènijos karinių pajëgumų didinimą galime laikyti taktinio lygmens veiksmu, siekiant atremti didejjantị spaudimą iš Azerbaidžano pusés.

Vertinant abiejų konflikto šalių laikyseną, matyti, kad menką karinị potencialą, palyginti su Azerbaidžanu, Arménija kompensuoja saugumo garantijomis ir išores parama karineje srityje (iš Rusijos).

Strateginiu lygmeniu Armenijos saugumo garantas yra jos naryste Kolektyvinio saugumo sutarties organizacijoje (KSSO), kur Rusijos įtaka yra dominuojanti. Kolektyvinio saugumo sutartis numato, kad vienos iš organizacijos šalių užpuolimas yra laikomas visų šalių užpuolimu ${ }^{44}$. Nors Kalnų Karabachas ir kiti Armenijos kontroliuojami Azerbaidžano regionai nèra laikytini Armėnijos teritorija, tačiau, turint omenyje Rusijos-Gruzijos 2008 m. karo precedentą, Rusijos veiksmai Arménijos-Azerbaidžano karinio konflikto atveju galètų būti gana neprognozuojami. Juolab kad Rusija yra suinteresuota išlaikyti Kalnų Karabacho problemą - kol kas vienintelị įrankị, igalinantị bent kiek paveikti Azerbaidžano politiką. Be to, Rusijos karinés pajegos Arménijoje turi gana stiprias pozicijas: netoli Giumri miesto yra dislokuota Rusijos karine bazè, kurios buvimo šalyje terminas buvo pratęstas iki 2044 m. su galimybe pratęsti iki 2049 m. mainais už Rusijos suteiktas saugumo

\footnotetext{
${ }^{39}$ International Crisis Group, Conflict Resolution in the South Caucasus: the EU's Role (išnaša 16), p. 8.

${ }^{40}$ German T. (išnaša 9), p. 3

${ }^{41}$ Jarosiewicz A., Strachota K., „Nagorno-Karabakh - Conflict Unfreezing“, OSW Commentary, p. 3.

${ }^{42}$ Regnum, Создано Министерство оборонной промьгиленности Азербайджана, 2005 m. gruodžio $16 \mathrm{~d}$.

${ }^{43}$ Regnum, В Азербайджане создано Министерство ирезвычайных ситуачий, 2005 m. gruodžio $16 \mathrm{~d}$.

${ }^{44}$ Аоговор о колмективной безопасности, http://www.dkb.gov.ru/b/azb.htm, 26112011.
} 
garantijas Armėnijai ${ }^{45}$. Be to, Rusijos karinès pajègos dalyvauja Armenijos-Turkijos sienos apsaugoje.

Kaip buvo minèta, Azerbaidžanas laikosi neutralios saugumo strategijos ir šiuo metu jokių išorinių saugumo garantijų neturi ir nedemonstruoja aspiracijų jų iggyti ateityje. Azerbaidžanas kilus konfliktui su Arménija galètų tikètis paramos iš Turkijos. Kita vertus, Turkija yra NATO nare, taigi jos galimybès vienašališkai palaikyti Azerbaidžaną yra labai ribotos.

Taigi šiame kontekste „klasikine““ Azerbaidžano taikoma atgrasymo strategija pralaimi Arménijos išorinèms saugumo garantijoms. Kitaip tariant, Kalnų Karabacho kontekste „atgrasomas“ Azerbaidžanas, o ne Arménija - Arménija jau yra užèmusi ir kontroliuoja maksimalią Azerbaidžano teritoriją, o nuo karinių veiksmų inicijavimo Baku atbaido būtent Armenijos turimos išorinès saugumo garantijos. Azerbaidžanas suvokia, kad Kalnų Karabacho karo atveju šiandien, kaip ir prieš du dešimtmečius, realiai turètų kariauti su Rusija, ne su Arménija. Tokiu atveju karas vestų ne tik į dar vieną pralaimëjimą, bet ir į prekybos angliavandeniliais (nafta ir dujomis) su Rusija, o greičiausiai - ir su Vakarais (dèl Azerbaidžano kaip tiekëjo nestabilumo) pabaigą. Tai suduotų stiprų smūgi šalies ekonomikai ir padarytų Azerbaidžano neutralią saugumo strategiją beprasmę ir betikslę.

Esant įtemptai paděčiai fronto linijoje ir išsilaikant abiejų konflikto šalių ginklavimosi tendencijai, konfliktas bet kada gali peraugti i „ "karštą “ fazę. Šiame kontekste situacijos nestabilumą didinantis veiksnys - drastiškas Azerbaidžano karinių išlaidų augimas. Baku argumentuoja, kad didindama karinę galią siekia spausti Armèniją ieškoti kompromiso, tačiau praktiškai Jerevanas atsako tik bandydamas vytis augančius Baku karinius išteklius ir stiprindamas išorines saugumo garantijas. Arménijos turimos išorinès saugumo garantijos sulaiko Baku nuo radikalių veiksmų, tačiau situacijos sprendimui ir kompromiso tarp konflikto šalių paieškai pastarosios garantijos neduoda jokios pridètinès vertès. Iš esmés Rusijos saugumo garantijos Arménijai ir yra Kalnų Karabacho konfliktą „į̌saldantis“ veiksnys. Taikos derybas „imitacinėmis“ daro ir abiejų šalių nereagavimas į tarptautinès bendruomenès spaudimą patraukti snaiperius nuo abiejų šalių karinių pajejgų kontaktinès linijos ${ }^{46}$.

Tačiau „išaldyta“ konflikto fazè iš tiesų slepia didëjantị atotrūkị tarp konflikto zonos ir Azerbaidžano bei augantị pastarojo nepasitenkinimą ir nusiteikimą vienašališkais veiksmais pakeisti ydingą status quo situaciją ${ }^{47}$.

\footnotetext{
${ }^{45}$ Express.am, Rusia Gave Guarantees to Armenia After Clinton's Visit: Ariel Cohen, 2010 m. rugpjūčio $11 \mathrm{~d}$.

${ }^{46}$ RFE/RL, US: Armenia, Azerbaijan „Must Pull Out Snipers“, 2011 m. kovo 19 d.

${ }^{47}$ Kapitonenko M., (išnaša 37), p. 36.
} 


\subsection{Tarptautinès bendruomenès ịsitraukimas ị taikaus Kalnų Karabacho konflikto sureguliavimo procesą}

Tarptautinès bendruomenès įsitraukimas į Kalnų Karabacho konflikto, kaip ir kitu „išaldytų" konfliktų posovietinëje erdvëje, sureguliavimą buvo ir išlieka ribotas.

İ konflikto taikaus sureguliavimo procesą yra įsitraukusi tik Europos saugumo ir bendradarbiavimo organizacija (ESBO). $1992 \mathrm{~m}$. turëjo įvykti Europos saugumo ir bendradarbiavimo konferencijos (dabartiné Europos saugumo ir bendradarbiavimo organizacija) rengiama Minsko konferencija Kalnų Karabacho klausimu. Konferencija taip ir nebuvo surengta, bet joje turejusių dalyvauti šalių pagrindu sukurta ESBO Minsko grupe, ėmusi tarpininkauti tarp Armėnijos ir Azerbaidžano Kalnų Karabacho klausimu. 1994 m. nuspręsta, kad ESBO Minsko grupei pirmininkaus JAV, Rusijos ir Prancūzijos diplomatai - iki 2008-ųjų jie veikè kaip tarpininkai tarp Arménijos ir Azerbaidžano taikių derybų procese. Tačiau, 2008-ųjų viduryje ị šalies prezidento postą atejus Dmitrijui Medvedevui, tarpininkavimą aukščiausio lygio Arménijos ir Azerbaidžano susitikimams peremé Rusija.

Tiesioginiai reguliarūs Arménijos ir Azerbaidžano prezidentų susitikimai vyksta nuo 2003 m. gruodžio mẻn.(atëjus į prezidento postą Ilhamui Alijevui), tačiau jų metu progreso nepasiekta. Abi šalys laikosi principingos ir nelanksčios pozicijos.

Nuo 2005-ųjų Armėnija ir Azerbaidžanas derejosi dèl principų, kuriais remiantis vyks derybos dèl taikaus Kalnų Karabacho konflikto sureguliavimo. Šie principai buvo patvirtinti $2007 \mathrm{~m}$. ESBO susitikime Madride (todèl vadinami Madrido principais) ir apima tris pagrindinius elementus: jègos nenaudojimą, teritorinio integralumo principo išlaikymą ir teisę į apsisprendimą ${ }^{48}$. Visgi, nors abi konflikto pusès yra pritarusios Madrido principams, nesutarimai išlieka.

Be to, derybų eiga ir progresas yra viešai nedeklaruojami - dèl didelio abieju konfliktuojančių pusių visuomenių jautrumo su Kalnų Karabacho konflikto sureguliavimu susijusioms temoms ${ }^{49}$ buvo nuspręsta, kad bus paskelbtas tik visas sureguliavimo principų ir priemonių, dèl kurių Armènija ir Azerbaidžanas bus sutarę, paketas.

Tarptautinè bendruomenè remia Azerbaidžano teritorinio vientisumo principą. Jungtinių tautų organizacija $1993 \mathrm{~m}$. prièmé keturias rezoliucijas, raginančias Armėniją nutraukti Azerbaidžano teritorijos okupaciją. Šiose rezoliucijose Kalnų Karabachas traktuojamas kaip Azerbaidžano dalis ${ }^{50}$.

\footnotetext{
${ }^{48}$ International Crisis Group, Nagorno-Karabakh: Getting to a Breakthrough, Policy Briefing, European Briefing No. 55, 7 October 2009, p. 5.

${ }^{49}$ Ten pat (išnaša 48), p. 7.

${ }^{50}$ Blandy C. W. „Azerbaijan: is war on Nagorny Karabakh a realistic option?“ Defence Academy of the United Kingdom, May 2008, p.4.
} 
Visgi tuo pat metu Armėnijos pozicija Kalnų Karabacho konflikto atžvilgiu nesusilaukia tarptautinio pasmerkimo ar didesnio spaudimo. Arménijai pavyko tarptautinę bendruomenę „„tikinti“ savąja konflikto versija, t. y. kad Kalnų Karabachas - istorinès arménų žemès, regione gyvena išskirtinai armėnų tautybès gyventojai, o konfliktas kilo dèl Azerbaidžano netinkamo elgesio su Kalnų Karabacho armènais bei Baku atsisakymo suteikti regiono gyventojams teisę i apsisprendimą. İdomu yra ir tai, kad tarptautines bendruomenès demesys yra atkreipiamas tik i situaciją pačiame Kalnų Karabache, o faktas, kad Armenijos karinès jegos yra užemusios dar septynis Azerbaidžano regionus, neturinčius jokio ryšio su etnine armẻnų gyvenamąja vieta, nèra plačiai žinomas ir nesulaukia atitinkamos reakcijos. Galima daryti išvadą, kad parama Azerbaidžano teritoriniam vientisumui yra dalis „bendrosios formules“, tačiau Armenija sugebejo tarptautinei bendruomenei „ištransliuoti“ savąją konflikto versiją. Tokia situacija rodo, kad Arménija valdo didesnę specifinę struktūrinę galią nei Azerbaidžanas.

Kalnų Karabacho konflikto eiga išryškina pagrindinę Azerbaidžano silpnąją vietą - menką sugebèjimą sutelkti specifinę (su konkrečia problema susijusia) struktūrinę galią. Nors Azerbaidžano tarptautinè pozicija yra geresnè nei Armėnijos, tarptautinëje bendruomenëje įsitvirtinusi „armėniškoji“ Kalnų Karabacho konflikto versija. Situaciją dar labiau komplikuoja nuolat demonstruojamos karingos Azerbaidžano nuotaikos - pradedant karinès doktrinos nuostatomis, viešais politikų pareiškimais ir baigiant drastišku karinio biudžeto didinimu. Pirma, kaip parode Gruzijos-Rusijos 2008 m. karas, ginkluotas , „išaldytų“ konfliktų sprendimas tik dar labiau komplikuoja esamą situaciją. Antra, neįmanoma, kad Azerbaidžanas galettu pradèti karinius veiksmus, nesulaukdamas tarptautinès bendruomenès reakcijos, t.y. neprarasdamas viso bendradarbiavimo ,idirbio“. Ir galiausiai, dèl karingų pareiškimų tarptautinei bendruomenei Azerbaidžanas atrodo agresyvus ir tokiu būdu netiesiogiai prisideda prie „armėniškojo“ konflikto aiškinimo įsitvirtinimo.

\section{Energetikos politika kaip Azerbaidžano galios šaltinis}

Energetikos politika, kaip pagrindinis Azerbaidžano struktūrinès ir santykinès galios augimo šaltinis, ị pirmą planą iškilo vienu metu pasireiškus šiems veiksniams: Azerbaidžano pasirengimui eksploatuoti gausius naftos ir dujų klodus, šalies siekiui užimti reikšmingą vietą tarptautinëje energetikos politikoje bei poreikiui iš ES ir JAV pusès mažinti priklausomybę nuo dominuojančių nestabilių energijos išteklių tiekëjų. Unikalus fizinių pajegumų, aspiracijų ir išorinès paklausos derinys 
leido Azerbaidžanui tapti vienu iš svarbiausių žaidëjų alternatyvių naftos ir dujų tiekimo maršrutų iš Kaspijos jūros regiono ị Vakarus projektuose.

Nors Azerbaidžano energetikos politikos plètra per pastarąji dešimtmeti vyko bemaž geometrine progresija, vis dar išlieka keletas išorinių veiksnių, galinčių sustabdyti šalies energetikos sektoriaus augimą. O tokiu atveju Azerbaidžanas ne tik susidurtų su rimtomis vidinemis problemomis, bet ir prarastų pagrindinị poveikio išorinei aplinkai svertą.

\subsection{Energetikos sektoriaus plètra: Baku „sẻkmès istorija“}

1993 m. Azerbaidžano prezidentu tapęs Heidaras Alijevas (buvęs ilgametis Azerbaidžano SSR komunistų partijos centro komiteto pirmasis sekretorius) suvoke energetikos svarbą Azerbaidžano vystymuisi ir tarptautinès padèties išsikovojimui. Tuometinio prezidento iniciatyva Azerbaidžano naftos ir dujų sektorius buvo atvertas užsienio investuotojams, ir tai leido į šalį pritraukti labai reikalingų užsienio investicijų tapo modernios Azerbaidžano energetikos politikos pagrindu.

Per paskutini XX a. dešimtmetį buvo pasirašyti svarbiausi susitarimai su užsienio kompanijomis dèl šalies naftos ir dujų telkinių eksploatavimo. $1994 \mathrm{~m}$. pasirašytas vadinamasis „Tūkstantmečio kontraktas“ dèl Azeri-Širako-Giunešli telkinių eksploatavimo, į kurị îsitraukè tokios kompanijos kaip BP, Amoco, Statoil, Exxon ir kt. 1995 m. Azerbaidžanas ir užsienio investuotojai pasirašè kontraktą dèl Karabacho telkinio eksploatavimo, 1996 m. - dèl Šahdenizo telkinio, 1997 m. - dèl Lenkoran-Denizo telkinio eksploatavimo ${ }^{51}$. Iš Azerbaidžano pusès šiuos telkinius eksploatuojant dalyvauja valstybinè Azerbaidžano naftos kompanija (SOCAR - State Oil Company of the Azerbaijan Republic).

Šiandien Azerbaidžano naftos ištekliai siekia $7 \mathrm{mlrd}$. barelių ${ }^{52}$, dujų $-849,5$ mlrd. kubinių metrų ${ }^{53}$. Metinis naftos išgavimas siekia daugiau nei $50 \mathrm{mln}$. tonų (2010 m. - 50,8 mln. t., 2009 m. - 50,4 mln. t. $)^{54}$, dujų išgauta 2010 m. - 26,3 mlrd. kubinių metrų, 2009 m. - 23,6 mlrd. kubinių metrų ${ }^{55}$. Šalis eksportuoja

\footnotetext{
${ }^{51}$ Blandy C. W., The Caucasus Region and Caspian Basin: Change, Complication and Challenge, https:// da.mod.uk/colleges/arag/document-listings/caucasus/S36.pdf, p. 3-5.

${ }^{52}$ Central Intelligence Agency, The World Factbook, https://www.cia.gov/library/publications/the-world-factbook/rankorder/2178rank.html, 15122011.

${ }^{53}$ Central Intelligence Agency, The World Factbook, https://www.cia.gov/library/publications/the-worldfactbook/geos/aj.html, 15122011.

${ }^{54}$ SOCAR, http://new.socar.az/socar/en/economics-and-statistics/economics-and-statistics/oil-production, 17 122011.

55 SOCAR, http://new.socar.az/socar/en/economics-and-statistics/economics-and-statistics/gas-production, 17 122011.
} 
naftą ir dujas ị Rusiją, Gruziją, Iraną, Turkiją. 2005-aisiais pradëjo funkcionuoti naftotiekis Baku-Tbilisis-Džeichanas (Baku-Tbilisi-Ceyhan, BTC), kurio pralaidumas siekia $50 \mathrm{mln}$. tonų naftos per metus ( $1 \mathrm{mln}$. barelių naftos per diena). Nuo 2006 m. veikia dujotiekis Baku-Tbilisis-Erzurumas (BTE), kurio metinis pralaidumas - 20 mlrd. kubinių metrų dujų. Taip pat veikia naftotiekis BakuNovorosijskas, Baku-Supsa, Baku-Potis.

Dar platesnés galimybès Azerbaidžanui panaudoti savo gausų naftos ir duju sektoriu atsivere nuo XXI a. pr., kuomet Vakarams kilo poreikis diversifikuoti energetinių žaliavų tiekimo šaltinius ir maršrutus bei mažinti priklausomybę nuo nestabilių tiekejjų. ES jau nuo $2002 \mathrm{~m}$. puoselëja ambicingą „Pietinio koridoriaus“ planą. „Pietinį koridorių“ turètu sudaryti keturi dujotiekiai: „Nabucco“, Kaspijos baseino dujas gabensiantis per Turkiją, Bulgariją, Rumuniją, Vengriją i Austriją; „Baltoji srové“, kuriuo Azerbaidžano dujos būtu gabenamos per Gruziją, Juodąją jūrą i Ukrainą ir Rumuniją; 8 mlrd. kubinių metrų per metus dujų galesiantis gabenti dujotiekis, sujungsiantis Turkiją, Graikiją ir Italiją (TGI), kuris šakotųsi nuo Baku-Tbilisio-Erzurumo dujotiekio; po 10 mlrd. kubinių metrų duju kasmet iš Graikijos per Albaniją ir Adrijos jūrą i Italiją pergabensiantis Adrijos dujotiekis (TAP).

Reikšmingiausias iš išvardytų „Pietinio koridoriaus“ projektų yra dujotiekis „Nabucco“, kuri planuojama nutiesti iki 2017 m. (projekto pabaigos terminas jau kelis kartus atidetas - L. K.). „Nabucco“ pajegumas pirminiame etape turètų siekti 8 mlrd. kubinių metrų dujų per metus, po to padidintas iki $31 \mathrm{mlrd}$. kubinių metrų dujų per metus.

Be to, Azerbaidžanas, Gruzija ir Rumunija yra sutarę dèl dujotiekio AGRI (Azerbaijan-Georgia-Romania International) projekto. Pagal šį projektą Azerbaidžano dujos turètu pasiekti Gruzijos Počio uostą, kuriame planuojama pastatyti suskystintų dujų terminalą. Suskystintos dujos tanklaiviais keliautų į Rumuniją, kur būtų transformuojamos atgal į dujas ir per Rumuniją pasiektų Europos vartotojus. 6-8 mlrd. kubinių metrų metinio pajegumo AGRI linija galetų pradèti veikti 2014 metais.

Azerbaidžano patrauklumą tarptautiniams energetikos projektams pirmiausia lemia patogi šalies geostrateginè padètis - galimybe Kaspijos jūros energijos išteklius gabenti nepaliečiant nei Rusijos, nei Irano.

Antra, Azerbaidžano privalumas yra tai, kad šalies energetikos sektorius nèra politizuotas. Beje, aktyvios išorinès energetikos politikos formavimo pradžioje svarbų vaidmenį atliko ir politinis Azerbaidžano neutralumas, leidęs plètoti energetinius ryšius naujomis kryptimis (pvz., Vakarų kryptimi).

Trečia, Baku laimi papildomų dividendų ir dèl demonstruojamo pasirengimo dalyvauti Vakaru remiamuose energetikos projektuose. Nuolatinis paramos 
Vakarų energetikos poreikiams demonstravimas yra ir nemenkas iššūkis šaliai, nes minètų alternatyvų plètra dažnai „užstringa“ nesibaigiančių diskusijų ir svarstymų stadijoje, o praktinis progresas yra lètas. Pesimistinio scenarijaus atveju vidutiniuilguoju laikotarpiu Azerbaidžanas galètų susidurti su situacija, kad šalis turi daugiau išgautų angliavandenilių negu galimybių juos realizuoti. Papildomu iššūkiu tampa ir Rusijos bei Irano demonstruojamas noras didinti perkamų Azerbaidžano angliavandenilių apimtis. Visgi kol kas Azerbaidžano parama ES projektuojamiems dujų tiekimo maršrutams yra stabiliausia visoje tiekimo ir tranzito zonoje.

Ir galiausiai, Azerbaidžano, kaip energijos išteklių tiekëjo, statusą labai sustiprino sèkmingai igyvendinti naftotiekio BTC ir dujotiekio BTE projektai. Funkcionuojantys angliavandenilių tiekimo maršrutai įrodẻ Azerbaidžano patikimumą ir patvirtino, kad alternatyvūs maršrutai nèra vien teorinès galimybès.

Azerbaidžanas savo energetikos politiką mato kaip pagrindinị šaltinį nepriklausomumui nuo išorès jègu didinti. ${ }^{56}$ Taigi stipri energetikos politika yra pagrindine šalies neutraliteto prielaida. Tuo pat metu neutralumas Azerbaidžanui leidžia maksimaliai stiprinti energetinius ryšius su išore ịvairiomis kryptimis. Dar daugiau, neutraliteto sąlygotą pasyvumą tarptautinès bendruomenès atžvilgiu kompensuoja aktyvi energetikos politika, tampanti vienu iš Baku politikos svertų.

Energetika yra pagrindinis struktūrinès ir santykinès Azerbaidžano galios augimo šaltinis - 90 proc. šalies eksporto sudaro nafta ir dujos, energetikos sektorius pritraukia didžiąją užsienio investicijų dalį. Sẻkmingai igyvendintų stambių naftos ir dujų transportavimo maršrutų patirtis ir naujų projektų gausa byloja apie augančią struktūrinę Azerbaidžano galią.

Visgi energetikos buvimas vieninteliu šalies „varikliu“ kelia vadinamosios „olandiškos ligos" grèsmę - reiškinį, kai dèl valiutos kursų svyravimo gamtinius išteklius eksportuojančių šalių pramonès sektorius tampa mažiau konkurencingas. Be to, Azerbaidžano ekonomine gerové priklauso nuo nestabilaus naftos ir duju kainų veiksnio, o „stabilesnę“ pridedamąją vertę kuriantys sektoriai šalyje yra silpnai išplètoti. Azerbaidžano poreikị plètoti ne su nafta ir dujomis susijusias ekonomikos sritis pabrèžia ir Tarptautinis valiutos fondas - pasak jo, $2011 \mathrm{~m}$. jau pasireiške naftos ir dujų sektoriaus pelningumo sumažèjimas, dẻl ko šalies vyriausybẻ negavo dalies planuotų ịplaukų. Tokios tendencijos turètų išsilaikyti dar keletą ateinančių metų, todèl ekonomikos diversifikavimas, ne su angliavandeniliais (nafta ir du-

\footnotetext{
${ }^{56}$ Alieva L, "Delivering Oil to the Countries of the Black Sea and Baltic Sea Regions: Interests and Possibilities for Azerbaijan", Building Energy Security: Cooperation among the Baltic, Black and Caspian Sea regions. International conference, 5 December 2006, Vilnius, Lithuania, Centre for Strategic Studies, 2007, p. 79-80.
} 
jomis) susijusių ekonomikos sektorių svarbos didinimas turetų būti artimiausio laikotarpio Azerbaidžano valdžios prioritetai ${ }^{57}$.

\subsection{Provakarietiška Baku energetikos politika: išorinès kliūtys}

Dèl neutraliteto politikos Azerbaidžanas turi galimybę prekiauti angliavandeniliais visomis įmanomomis krytimis, visgi lemiamą įtaką šalies santykinès ir struktūrinès galios augimui turi energetikos politikos plètra Vakarų atžvilgiu. İdomu ir tai, kad po sèkmingo naftotiekio BTC ir dujotiekio BTE projektų igyvendinimo galimybe pirkti Azerbaidžano naftą ir dujas labiau susidomëjo ir kitos valstybès (pvz., Rusija ir Iranas).

Nors Baku provakarietiška energetikos politika pažymèta sẻkmingų precedentų, jos plètrai ateityje kyla keletas grèsmių iš išorès - nesureguliuotas Kaspijos jūros teisinis statusas ir energetikos projektų konkurencija regione.

\subsubsection{Nesureguliuotas Kaspijos jūros teisinis statusas}

Kaspijos jūros teisinio statuso problema yra viena pamatinių kliūčių, galinti „išaldyti“ stambių Rusiją ir Iraną apeinančių energetikos projektų plètrą Kaspijos jūros baseine neribotam laikui.

Nesutarimai dèl Kaspijos jūros teisinio statuso tarp penkių Kaspijos baseino valstybių - Rusijos, Azerbaidžano, Kazachstano, Turkmenistano ir Irano - prasidejo dešimtojo XX a. dešimtmečio antroje puseje, šalims èmus aktyviai eksploatuoti Kaspijos jūros dugno išteklius. Šalys neranda kompromiso, ar Kaspijos jūrą, kuri geografiškai yra ežeras, teisiškai laikyti ežeru ar jūra. Jei Kaspijos jūra teisiškai būtų laikoma ežeru, visi jos ištekliai privalètų būti dalijami visoms penkioms Kaspijos baseino valstybèms lygiomis dalimis (ar kitu būdu, dèl kurio sutare visos pakrantès šalys). Tačiau jei Kaspijos jūrą visgi būtų nutarta laikyti jūra, tuomet valstybei priklausytų tik tie naftos ir duju ištekliai, kurie yra jos teritoriniuose vandenyse ${ }^{58}$. Sovietų Sąjungos gyvavimo laikais su Kaspijos jūra ribojosi dvi valstybès: SSRS ir Iranas. Tuomet Kaspijos jūra buvo laikoma ě̌eru, o visi iš jos išgaunami ištekliai lygiomis dalimis dalijami tarp SSRS ir Irano. Iki šiol su Kaspijos jūra susijusius

\footnotetext{
${ }^{57}$ International Monetary Fund, Republic of Azerbaijan- Concluding Statement of the 2011 Article IV Consultation Mission, Baku, October 30, 2011, http://www.imf.org/external/np/ms/2011/103011.htm, 12 112011.

${ }^{58}$ Andianopoulos A., "The economics and politics of Caspian oil” in Hunter S. (ed.), Strategic developments in Eurasia after 11 September. London, Frank Cass, 2004, p. 84-85.
} 
klausimus reglamentuoja du susitarimai, pasirašyti tarp SSRS ir Irano $1921 \mathrm{~m}$. ir 1940 metais $^{59}$.

Azerbaidžanas ir Kazachstanas, šalys, kurių teritoriniuose vandenyse yra daugiausia naftos ir dujų išteklių, suinteresuoti, kad Kaspija teisiškai būtų laikoma jūra. Iranas, kuriam priklausančiuose Kaspijos teritoriniuose vandenyse angliavandenilių (naftos ir dujų) telkinių beveik nèra, pasisako griežtai už ežero statusą. Turkmènistanas dar neturi tvirtos pozicijos šiuo klausimu, nes turi daug neišspręstų ginčų dẻl angliavandenilių (naftos ir dujų) telkinių priklausomybès su Iranu ir Azerbaidžanu. Be to, šalis turi gausias žemés dujų atsargas, tad Kaspijos dujos ir nafta Turkmenistanui nèra ekonomiškai būtinos. Tai įvertinęs, Turkmènistanas būtų labiau linkęs Kaspijos jūros pakranteje plètoti turizmą, o ne naftos ir dujų gavybą.

Rusija šioje situacijoje užima dvilypę poziciją. Viena vertus, ji pasirašè dvišales sutartis su Azerbaidžanu ir Kazachstanu dẻl teritorinių vandenų ribos nustatymo. Kita vertus, Maskva remia Teherano laikyseną dẻ ežero teisinio statuso Kaspijai suteikimo. Rusijos tikslas - ne angliavandenilių resursų, o jų transporto kontrolè. nes, kol nėra nustatytas vandens telkinio statusas, jokie tarpvalstybiniai projektai igyvendinami būti negali.

Vakarų remiamiems alternatyviems naftos ir dujų tiekimo maršrutams igyvendinti būtini Kaspijos dugnu einantys naftotiekiai ir dujotiekiai, jungiantys Kazachstaną ir Turkmenistaną su Azerbaidžanu ir užtikrinantys mažiausiai sąnaudų reikalaujantị būdą gausiems Vidurio Azijos valstybių naftos ir dujų ištekliams pasiekti - Azerbaidžaną, o iš čia - ir vartotojus Europoje.

Jei Kaspijos dugnu einantys vamzdynai būtų nutiesti iki teisinio Kaspijos jūros statuso nustatymo, ežero atveju jie taptų visų penkių šalių nuosavybe, o šios galètų pareikalauti jų išmontavimo. Dẻl šios priežasties nesiryžtama investuoti i ǐ šių vamzdynų tiesimą, o Kazachstano ir Turkménistano naftos ir dujų gabenimas tanklaiviais yra brangus.

Azerbaidžano išgaunamų angliavandenilių šiuo metu užtenka užpildyti tik esamiems vamzdynams. Nors Baku ketina ateityje didinti naftos ir dujų išgavimą, produkcija neišaugs taip stipriai, kad patenkintų ES naftos ir dujų poreikio deficitą. Tačiau jei būtų igyvendinti alternatyvūs naftos ir dujų tiekimo maršrutų projektai, be Kazachstano ir Turkménistano dalyvavimo jie būtų sunkiai įmanomi.

\subsubsection{ES ir Rusijos konkurencija dèl naujų energetikos projektų regione}

Rusija deda visas pastangas, siekdama išvengti ją apeinančių naftos ir dujų transportavimo į ES projektų realizavimo.

\footnotetext{
${ }^{59}$ Blandy C. W., The Caucasus Region and Caspian Basin: Change, Complication and Challenge (išnaša 51), p. 16.
} 
Kaip alternatyvą ES remiamam „Nabucco“ projektui Maskva yra pateikusi „Pietinès srovès“ dujotiekio projektą. Dujotiekio, kurio tiesimas planuojamas baigti $2015 \mathrm{~m}$., pralaidumas galètų siekti nuo $31 \mathrm{mlrd}$. kubinių metrų dujų per metus pradinëje stadijoje iki $63 \mathrm{mlrd}$. kubinių metrų dujų per metus galutinëje stadijoje 2018-aisiais. „Pietinès srovès“ maršrutas turetų eiti iš Rusijos Juodosios jūros dugnu iki Bulgarijos, o iš ten šakotųsi i dvi atkarpas, viena kurių eitų per Serbiją, Vengriją i Austriją, o kita - per Graikiją i Italiją.

Taigi, „Nabucco“ ir „Pietų srovès“ projektai yra beveik identiški. Todèl labiausiai tikètina, kad igyvendintas bus tik vienas iš ju - dujas Europai teiks tas dujotiekis, kuris bus nutiestas pirmiau. Pagrindine „Nabucco“ problema šiandien - neaiškus dujų tiekejjas. .Dèl nesureguliuoto Kaspijos jūros teisinio statuso ir politinio šaliu indiferentiškumo Kazachstano ir Turkmennistano dalyvavimas nèra garantuotas. Prie dujų tiekimo nestabilumo dujotiekiu „Nabucco“ grésmés prisideda ir jau kelis kartus tarp Azerbaidžano ir Turkijos kilę nesutarimai dèl Ankarai dujotiekiu BTE tiekiamų dujų tarifų ir už tranzitą tenkančiu dujų apimties. Iki šiol kompromisą rasti šalims pavykdavo, tačiau panašūs ginčai ateityje keltų grèsmę, kad „Nabucco“ ar kitas dujotiekis gali likti be dujų. Labiausiai nerimą kelia tas faktas, kad nesutarimai tarp Baku ir Ankaros dujų srityje dažniausiai kyla ne dèl ekonominių, o del politinių klausimų, tokių kaip Turkijos bandymas normalizuoti santykius su Armenija. Kaip pastebi ekspertai, nacionalinių interesu dominavimas derybose dèl regioninių energetikos projektų yra vienas pagrindinių rizikos veiksnių ${ }^{60}$.

Kita vertus, tranzito valstybès „Nabucco“ projektui demonstruoja aktyvu palaikymą - $2011 \mathrm{~m}$. birželi penkios tranzito valstybès - Turkija, Rumunija, Bulgarija, Vengrija ir Austrija - bei „Nabucco“ konsorciumas pasiraše paramos projektui susitarimą ${ }^{61}$, kuriame tranzito šalys įsipareigojo tiesiamam „Nabucco“ dujotiekiui taikyti palankiausią teisinį režimą ir nebloginti situacijos, o $2009 \mathrm{~m}$. birželį šios penkios tranzito valstybès pasirašè tarpvyriausybinį susitarimą dèl „Nabucco" dujotiekio tiesimo, kuriame pirmą kartą buvo išreikšta tranzito valstybių politiné parama projektui ${ }^{62}$.

Dar vienas Rusijos būdas laimèti „lenktynes“ dèl dujų transportavimo į ES maršrutu - supirkti kiek įmanoma daugiau vienintelio garantuoto tiekëjo „Nabucco“ dujotiekiui dujas. Iki 2007-ujju Azerbaidžanas importavo dujas iš Rusijos, o šiandien pati Rusija perka Azerbaidžano dujas ir siekia ịsigyti kuo didesnị ju

\footnotetext{
${ }^{60}$ Cornell Ph., ,"Turkey on the Energy Crossroads“, Per Concordiam, Journal of European Security and Defence Issues, Vol. 1 No. 1, March 2010, p. 31.

${ }^{61}$ New Europe, Nabuco Project Support Aggreement Singed by Each Transit Country, 2011 m. birželio 12 d.

62 Balcer A., Intergovernmental Agreement on Nabucco Case Signed, CEWEEKLY, Centre for Eastern Studies,

Warsaw, 2009-07-15.
} 
kiekį. Rusijos-Azerbaidžano susitarimas dèl dujų pirkimo buvo sudarytas 2009 m. viduryje, o 2010 m. 500 mln. kubinių metrų Azerbaidžano dujų pirmą kartą pasiekè Rusijos vartotojus ${ }^{63}$. Jau $2011 \mathrm{~m}$. Azerbaidžano ị Rusiją tiekiamų dujų apimtys išaugo keturis kartus iki 2 mlrd. kubinių metrų ${ }^{64}$, o per $2012 \mathrm{~m}$. Rusija ketina nupirkti 3 mlrd. kubinių metrų Azerbaidžano dujų ${ }^{65}$. Svarbu ir tai, kad $2011 \mathrm{~m}$. pradžioje Baku ir Teheranas pasiraše penkerių metų sutartį, pagal kurią Azerbaidžanas Iranui įsipareigojo parduoti mažiausiai po $1 \mathrm{mlrd}$. kubinių metrų dujų kasmet ${ }^{66}$.

Šiuo metu Azerbaidžano pozicija ES-Rusijos konkuravimo kontekste yra viena geriausių: Baku svarbus abiem konkuruojančioms pusèms, o tai sudaro prielaidas šaliai maksimaliai padidinti savo struktūrinę galią. Visgi jei Rusijos remiami angliavandenilių transportavimo į ES projektai nukonkuruotų Rusiją apeinančiuosius, tuomet Azerbaidžano svarba tiek Europos Sąungai, tiek pačiai Rusijai sumažetų.

\section{Išvados}

Kalnų Karabacho nesureguliuoto konflikto problema ir Azerbaidžano aspiracijos energetikos srityje visą laiką egzistavo lygiagrečiai ir veike viena kitą, tačiau teigiamo šios sąveikos poveikio stebima nebuvo. Šiuolaikinès Azerbaidžano energetikos politikos pradžia laikomas „Tūkstantmečio kontraktas“ buvo pasirašytas 1994-ųjų rudeni - po to, kai Baku ir Jerevanas susitare dèl paliaubų Kalnų Karabacho fronte, pasirašydami ugnies nutraukimo susitarimą. Tuomet buvo manoma, kad dèl energetikos plètros sustiprejusiam Azerbaidžanui bus lengviau išspręsti „išaldytą" konfliktą.

Visgi šiandien matome, kad, nepaisant ispūdingo Baku šuolio energetikos srityje, Kalnų Karabacho konflikto sureguliavimo procesas laukiamų rezultatų kol kas nedavè. Atvirkščiai, nesureguliuotas dalies Azerbaidžano teritorijos kontrolès klausimas bei dèl jo kylančios įtampos su kitomis regiono valstybèmis tampa trukdžiu tolesnei Azerbaidžano energetikos politikos pletrai.

Didžiausia problema Kalnų Karabacho konflikto sureguliavimo srityje Azerbaidžano išorinių saugumo garantijų neturejimas, kai Armėnija, būdama $\mathrm{KSSO}$ nare, jas turi. Be to, Armenija turi ir tiesiogines Rusijos saugumo garantijas,

\footnotetext{
${ }^{63}$ Socor V., Azerbaijan-Russia Gas Agreement: Implications for Nabucco Project, Eurasia Daily Monitoring, Volume: 6, Issue: 189, The Jamestown Foundation, October 152009.

${ }^{64}$ Ria Novosti, Russia's Gazprom Ready to Buy All of Azerbaijan's Gas - CEO Miller, 2010 m. birželio 19 d.

${ }^{65}$ Ria Novosti, Russia Extends Gas Purchase Contract With Azerbaijan, 2012 m. sausio 23 d.

${ }^{66}$ Bloomberg, Azerbaijan Signs Gas Supply Contract With Iran Before EU Visit, 2011 m. sausio 12 d.
} 
suteiktas sutikus pratęsti Rusijos karinès bazès buvimo Armėnijos teritorijoje terminą. Klasikinè atgrasinimo strategija Armėnija atžvilgiu taip pat neveikia, todèl Azerbaidžano karinių pajègumų augimas nèra tikslingas. Dar daugiau, priešingai nei mano šalies valdžia, karinių pajegumų stiprinimas ne tik kad neduoda jokios pridètinès vertes konflikto sprendimui, bet ir turi iš esmès destrukcini poveikį.

Pirma, karinių išlaidų augimas, kartu su karingais šalies politikų viešais pareiškimais, tarptautinei bendruomenei Azerbaidžaną leidžia matyti kaip agresorių, o tai mažina Baku prestižą tarptautinëje arenoje (struktūrinę galią). Antra, Azerbaidžano ginklavimasis didina viso regiono trapumą ir pažeidžiamumą - turint omenyje įtemptus regiono šalių santykius, konfliktas gali plykstelti bet kur. Galiausiai išlaidų gynybai didinimas „suryja“ didelę dalị sèkmingos energetikos politikos nešamų pajamų, kurios galètų būti panaudotos kitoms ekonomikos sritims pletoti.

Energetikos politika, nukreipta ị Vakarus, yra pagrindinis Azerbaidžano struktūrinès galios augimo šaltinis ir iš dalies kompensuoja išorinių saugumo garantijų trūkumą. Tačiau jos perspektyvos stipriai priklauso nuo veiksnių, kurių pats Baku negali kontroliuoti (Kaspijos jūros teisinio statuso problema, ES ir Rusijos energetinis bendradarbiavimas/konkurencija), todèl, pesimistinio scenarijaus atveju, Azerbaidžanas prarastų vieninteli savo svertą tarptautinès bendruomenés atžvilgiu.

Antra, šiuo metu Azerbaidžano deklaruojamas neutralitetas kaip diversifikuotos energetikos politikos pagrindas nebeatlieka savo funkcijos. Didžioji dalis Azerbaidžano eksportuojamų naftos ir dujų vamzdynais BTC ir BTE keliauja Vakarų kryptimi. Be to, išorinių saugumo garantijų turëjimas Baku nebūtų kliūtis tęsti jau įtvirtintą prekybą angliavandeniliais su kitomis šalimis. Atlikus analizę matyti, kad Azerbaidžano neutraliteto funkcija yra ne diversifikuoti energetikos politikos kryptis, o atsieti bendradarbiavimą energetikos srityje nuo plataus pobūdžio bendradarbiavimo, t.y. padaryti įmanomą glaudžią partnerystę su Vakarais energetikos srityje, išvengiant atitinkamų reikalavimų demokratizacijos, žmogaus teisių ir pan. srityse.

Baku savo politikoje remiasi abejotina nuostata, kad vienu metu yra įmanoma tik arba plataus masto energetikos politika, arba išorinès saugumo garantijos. Būtent šiuo metu yra susiklosčiusi situacija, kai potencialios išorinès saugumo garantijos ir Baku energetikos politika yra nukreiptos ta pačia kryptimi, taigi Azerbaidžano saugumo dilema šiuo aspektu gali būti išspręsta.

Visgi yra įmanomas ir „trečiasis“, kompromisinis kelias, galintis padèti Baku apeiti „nulinés sumos“ žaidimą - „arba teritorinis vientisumas, arba energetikos politika“, tuo pat metu išlaikant neutralumą.

Azerbaidžanas pasižymi nuolat augančia struktūrine galia, tačiau jo specifine 
struktūrinè galia Kalnų Karabacho konflikto sureguliavimo atžvilgiu yra menka. Šis atotrūkis ir lemia tai, kad, didejjant Azerbaidžano energetikos politikos svarbai Vakaruose, JAV ir ES demesys, skiriamas šalies teritorinio vientisumo atkūrimui ir greitesniam Kalnų Karabacho konflikto sureguliavimui, o tuo labiau spaudimas Arménijai, beveik nekinta. Tai rodo, kad šiuo metu pagrindinè Azerbaidžano santykių su Vakarais problema - susirūpinimą kelianti demokratijos situacija Azerbaidžane ir ne visai skaidrūs vidaus politikos procesai. Kol kas Armènija atrodo demokratiškesnè už Azerbaidžaną, todèl tarptautine bendruomené, spausdama Jerevaną ir palaikydama Baku, gali būti apkaltinta „dvigubų standartų“ laikymusi.

Siekdamas įveikti agreguotos ir specifinès struktūrinès galios atotrūkị, Azerbaidžanas turètų tarptautinei bendruomenei save pateikti ne kaip stiprų, o kaip atvirą ir patikimą veikèją. Kitaip tariant, Baku turetų Vakarų kryptimi orientuoti ne tik energetikos politiką, bet ir vidaus politikos procesus. Žengdamas „trečiuoju“ keliu, Baku pirmiausia turètų nutraukti militaristinių pareiškimų laviną ir sumažinti ginklavimosi augimo mastus, ir, antra, siekti maksimaliai demokratiškos, skaidrios ir atviros vidaus politikos, ịskaitant pagarbą žodžio, susirinkimų laisvei. Taikaus ir demokratiško Azerbaidžano vykdomos ambicingos energetikos politikos nauda vidutiniu-ilguoju laikotarpiu turètų duoti teigiamą poveikị ir sprendžiant Kalnų Karabacho „išaldytą“" konfliktą.

Vilnius, 2011 m. rugpjütis - 2012 m. kovas 